\title{
17. STRATIGRAPHY AND PLANKTONIC FORAMINIFERS OF CENOZOIC DEPOSITS OF THE BAY OF BISCAY AND ROCKALL PLATEAU, DSDP LEG 48
}

\author{
Valeri A. Krasheninnikov, Geological Institute of the USSR Academy of Sciences, Moscow, USSR
}

\section{INTRODUCTION}

During DSDP Leg 48 of the Glomar Challenger, drilling in the Bay of Biscay and on the Rockall Plateau at eight sites (399-406) (Figure 1) penetrated Cenozoic sediments of various thickness and stratigraphic completeness.

Zonal stratigraphy of Cenozoic deposits in the tropical belt of the world oceans has been thoroughly studied by means of planktonic foraminifers, but Cenozoic stratigraphy of higher latitudes is considerably less known. Because of the proximity of the Bay of Biscay to the Paris and Aquitain basins where stratotypes of some Paleogene and lower Miocene stages are already established, drilling in the Bay of Biscay and Rockall Plateau was important for elucidating (through planktonic foraminifers) the Cenozoic zonal and chronostratigraphic scale and the Cenozoic geologic history of the northeastern Atlantic Ocean.

The results of investigations of Leg 48 significantly supplement the findings of Leg 12 (Laughton, Berggren, et al., 1972; Berggren, 1972a, b, 1974; Poore and Berggren, 1975) on Cenozoic stratigraphy of the area. In the present study, 753 samples were taken for micropaleontological analysis; the number of samples studied in each of the holes is presented in Table 1.

\section{STRATIGRAPHY OF CENOZOIC SEDIMENTS IN THE SITES}

The stratigraphy and planktonic foraminiferal assemblages of Cenozoic sediments (Figures 2 and 3 ) of the Bay of Biscay and Rockall Plateau are distinguished by a number of features.

\section{Bay of Biscay}

In the north of the Bay of Biscay the drilling was carried out on the lower part of the continental slope at the base of the Meriadzek Terrace (Sites 399 and 400), where the water depth reaches almost 4.4 kilometers, and at much lesser depths in the middle part of the continental slope near the margin of the Meriadzek Terrace (Site 401), and to the north of this escarpment (Site 402).

\section{Sites 399 and 400}

Continuous coring at Site 400 (except for the interval 9.0-74.5 $\mathrm{m}$ within Quaternary sediments) produced an excellent stratigraphic record, 635 meters thick. The Cenozoic section commences with upper Paleocene sediments unconformably resting on Upper Cretaceous (Maestrichtian) deposits. The upper Paleocene-lowermost Eocene (Globorotalia formosa Zone) consists of yellowish calcareous claystones and greenish gray clay chalk. The balance of the lower Eocene and the middle Eocene section are com-

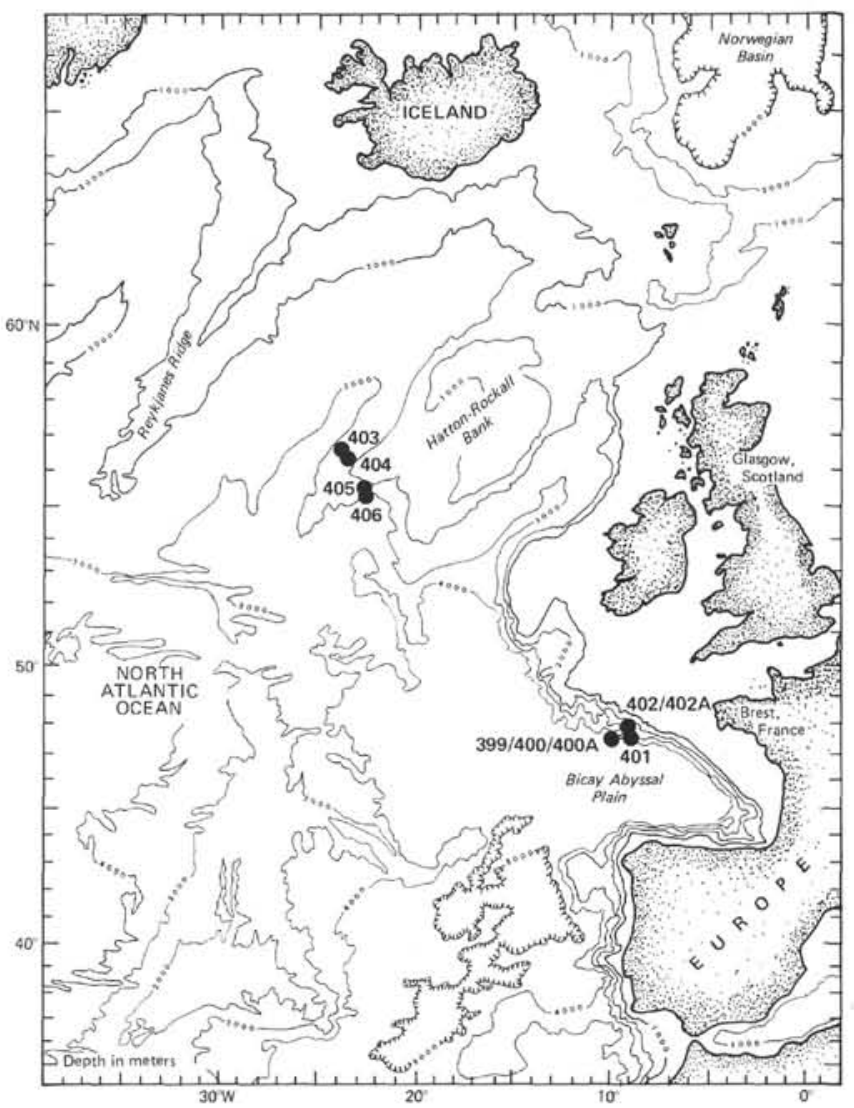

Figure 1. Location of Sites drilled on Leg 48.

TABLE 1

Data on Sites of Leg 48

\begin{tabular}{lcccccc}
\hline Hole & $\begin{array}{c}\text { Latitude } \\
(\mathrm{N})\end{array}$ & $\begin{array}{c}\text { Longitude } \\
(\mathrm{W})\end{array}$ & $\begin{array}{c}\text { Water } \\
\text { Depth } \\
(\mathrm{m})\end{array}$ & $\begin{array}{c}\text { Penetration } \\
(\mathrm{m})\end{array}$ & $\begin{array}{c}\text { Thickness } \\
\text { of Cenozoic } \\
(\mathrm{m})\end{array}$ & $\begin{array}{c}\text { Number of } \\
\text { Samples } \\
\text { Examined }\end{array}$ \\
\hline 399 & $47^{\circ} 23.4^{\prime}$ & $09^{\circ} 13.3^{\prime}$ & 4399 & 72.5 & 72.5 & 10 \\
400 & $47^{\circ} 22.9^{\prime}$ & $09^{\circ} 11.9^{\prime}$ & 4399 & 9 & 9 & 7 \\
$400 \mathrm{~A}$ & $47^{\circ} 22.9^{\prime}$ & $09^{\circ} 11.9^{\prime}$ & 4399 & 777.5 & 635 & 190 \\
401 & $47^{\circ} 25.65^{\prime}$ & $08^{\circ} 48.62^{\prime}$ & 2495 & 341 & 236.5 & 75 \\
402 & $47^{\circ} 52.48^{\prime}$ & $08^{\circ} 50.44^{\prime}$ & 2339.5 & 137 & 137 & 15 \\
$402 \mathrm{~A}$ & $47^{\circ} 52.48^{\prime}$ & $08^{\circ} 50.44^{\prime}$ & 2339.5 & 469.5 & 175 & 19 \\
403 & $56^{\circ} 08.31^{\prime}$ & $23^{\circ} 17.64^{\prime}$ & 2301 & 489 & 489 & 117 \\
404 & $56^{\circ} 03.13^{\prime}$ & $23^{\circ} 14.95^{\prime}$ & 2306 & 389 & 389 & 56 \\
405 & $55^{\circ} 20.18^{\prime}$ & $22^{\circ} 03.49^{\prime}$ & 2958 & 407 & 407 & 125 \\
406 & $55^{\circ} 15.50^{\circ}$ & $22^{\circ} 05.41^{\prime}$ & 2911 & 841 & 841 & 139 \\
\hline
\end{tabular}

posed of greenish gray siliceous mudstones with abundant radiolarians, sponge spicules, and interbeds of porcellanites. Oligocene sediments comprise yellowish and yellowish gray siliceous nannofossil chalk with abundant radiolarians and sponge spicules, the latter sometimes to abundant that the sediment is transformed into spongolite. 


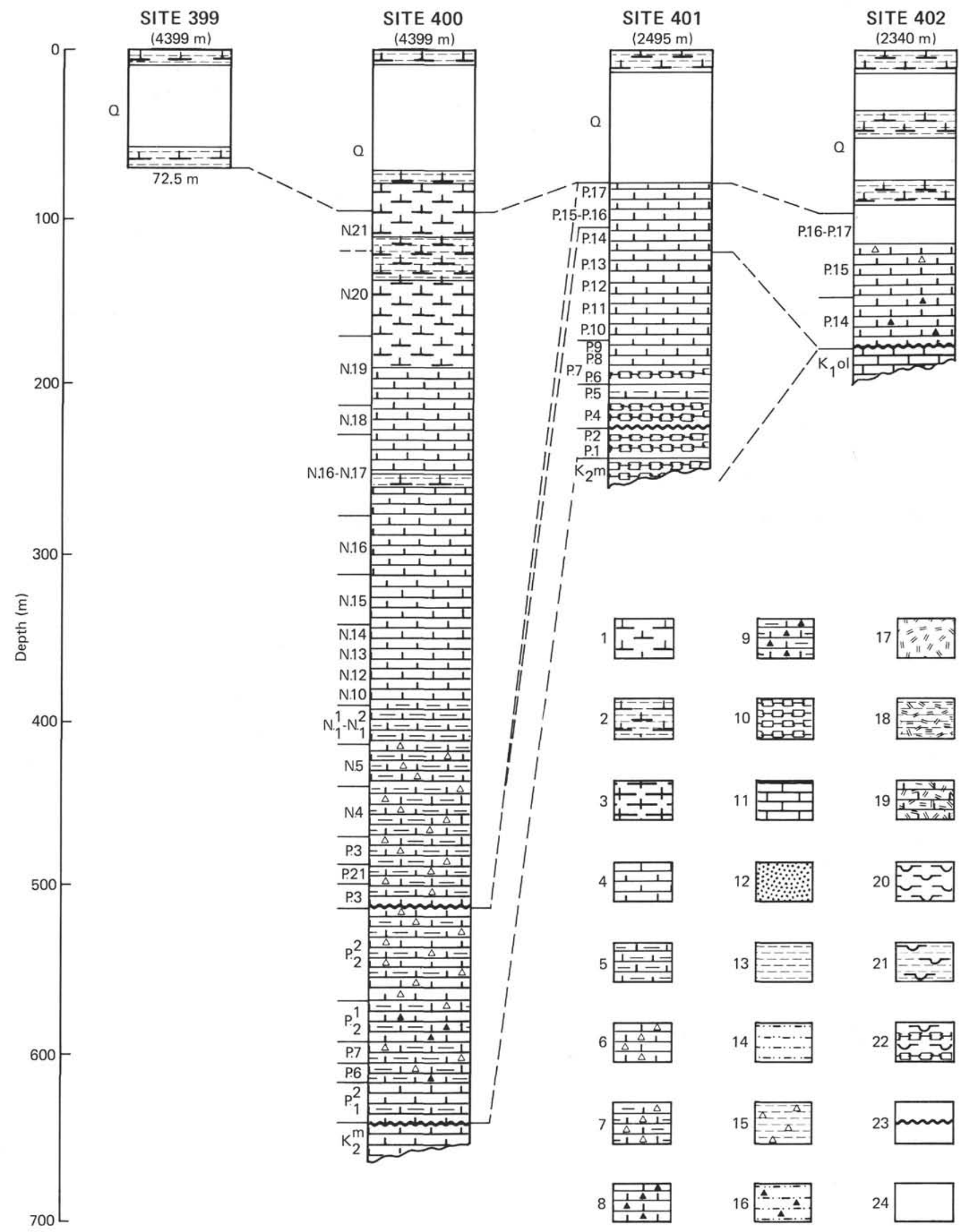


Figure 2. Stratigraphic correlation of the Cenozoic sediments penetrated by the DSDP holes in the Bay of Biscay. Stratigraphic symbols: $K_{1}$ al - Lower Cretaceous, Albian; $K_{2} m-$ Upper Cretaceous, Maestrichtian; $P_{1}$ ? $-P_{3}$ aleocene?; P2 Upper Paleocene; $P_{2}^{1}-$ Lower Eocene; $P_{2}^{2}-$ Middle Eocene; $P_{2}^{3}-$ Upper Eocene; $P_{3}-$ Oligocene; $N_{1}^{1}-$ Lower Miocene; $N_{1}^{2}$ - Middle Miocene; $N_{2}$ - Pliocene; $Q-$ Quaternary; Zones: P.1 - Globorotalia trinidadensis; $P .2$ - Acarinina uncinata; $P .4$ - Globorotalia pseudomenardii; P.5 - Globorotalia velascoensis; P.6 - Globorotalia subbotinae; $P .7$ - Globorotalia formosa; $P .8$ - Globorotalia aragonensis; $P .9$ - Globorotalia palmerae; $P .10$ - Hantkenina aragonensis s. 1 .; $P .11$ - Globigerapsis kugleri; $P .12$ - Globorotalia lehneri; $P .13$ - Orbulinoides beckmanni; $P .14$ - Truncorotaloides rohri; $P .15$ - Globigerapsis semiinvoluta; $P .16$ - Globorotalia cocoaensis; $P .17$ - Globigerina gortanii-Globorotalia centralis; $P .21$ - Globorotalia opima; P.22 - Globigerina ciperoensis; N.4 - Globigerinoides primordius-Globorotalia kugleri; N.5 - Globigerinita dissimilis; N.8 - Praeorbulina glomerosa; N. 9 - Orbulina suturalis-Globorotalia peripheroronda; N.10 - Globorotalia peripheroacuta; N.12 - Globorotalia fohsi lobata; N.13 - Sphaeroidinellopsis subdehiscens-Globigerina druryi; $N .14$ - Globigerina nepenthes-Globorotalia siakensis; N.15 - Globorotalia continuosa; $N .16$ - Globorotalia merotumida; $N .17$ - Globorotalia plesiotumida; N.18 - Globorotalia margaritae margaritae; N. 19 - Globorotalia margaritae evoluta; $N .20$ - Globorotalia miocenica; N.21 - Globorotalia tosaensis; $N_{2}$ cr - layers with Globorotalia crassaformis; $N_{2}$ inf layers with Globorotalia inflata. Lithologic symbols: 1 - nanno ooze, 2 - clayey nanno ooze, 3 - nanno foraminiferal ooze, 4 - nanno chalk, 5 - clayey nanno chalk, 6 - nanno chalk with siliceous organisms, 7 - clayey nanno chalk with siliceous organisms, 8 - silicified chalk, 9 - silicified clayey chalk, 10 - compact nanno chalk, 11 - limestone, 12 - sandstone, 13 - clay and claystone, 14 - aleuritic clay and claystone, 15 - clay with siliceous organisms, 16 - silicified aleuritic clay, 17 - tuff, 18 clayey tuff, 19 - tuffaceous nanno chalk, 20 - diatomite, 21 - diatomite clay, 22 - diatomite compact nanno chalk, 23 disconformities, 24 - uncored intervals. 


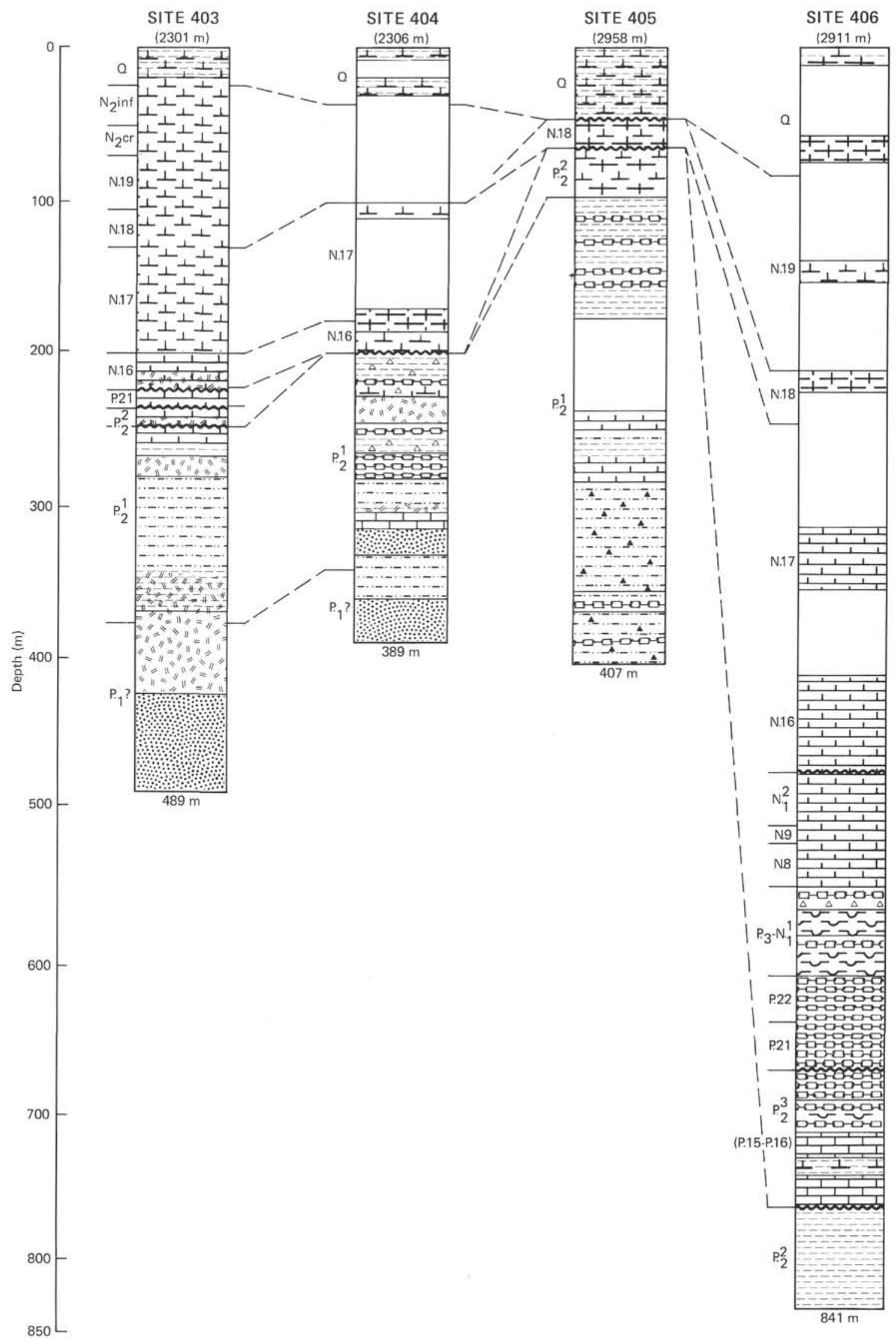

Figure 3. Stratigraphic correlation of the Cenozoic sediments penetrated by the DSDP holes on the Rockall Plateau. The same legend as for Figure 2. 
Lower Miocene deposits consist of alternating pale gray clayey chalk, nannofossil chalk, and calcareous claystones frequently enriched with remains of siliceous organisms (radiolarians, sponges). The lower Miocene-Quaternary are represented by pale gray and greenish nannofossil chalk and oozes and clayey nannofossil chalk and oozes.

Planktonic foraminifers from Cenozoic deep-water sediments at Site 400 were strongly affected by selective dissolution, especially in Paleogene and lower Miocene sediments; in this interval only a few zones can be established. In middle Miocene-Quaternary sediments planktonic foraminifers are more abundant, the entire succession of zones being recognizable because the foraminiferal assemblages are composed mostly of resistant species.

\section{Paleocene}

Upper Paleocene deposits (thickness, $27 \mathrm{~m}$; Samples 58, $\mathrm{CC}$ to $59-1,57-59 \mathrm{~cm}$ ) contain rare specimens of Globorotalia aff. velascoensis, Acarinina acarinata, A. mckannai, A. sp., and Globigerina nana.

\section{Eocene}

Eocene deposits, (thickness, $93 \mathrm{~m}$ ) are represented by a lower and a middle subseries; upper Eocene sediments are absent thus marking a hiatus below the overlying lower Oligocene beds.

Two early Eocene zones are identified: (1) the Globorotalia subbotinae Zone (Sample 57, CC) with the index species, G. aff. edgari, Acarinina pseudotopilensis, A. acarinata, A. mckannai, Globigerina nana, $G$. compressaformis. The microfauna appears to originate from the layers transitional to the upper Paleocene; (2) the Globorotalia formosa Zone (Sample 56-2, 39-41 cm), an assemblage of planktonic foraminifers that includes common Globorotalia formosa gracilis, $G$. marginodentata, G. subbotinae, Acarinina pseudotopilensis and rare Globorotalia aff. formosa formosa, Acarinina camerata, A. mckannai, and A. intermedia.

In the interval from Sample 54-1, 146-148 cm to Sample $55-2,58-60 \mathrm{~cm}$ (which contains enormous radiolarian accumulations) only sporadic Acarinina pentacamerata, $A$. interposita, Globigerina eocaenica, and G. pseudoeocaena were observed. These sediments tentatively can be assigned to the upper part of the lower Eocene (Globorotalia aragonensis and $G$. palmerae zones).

The middle Eocene is characterized by a poor planktonic foraminiferal assemblage. The boundary between the lower and middle Eocene tentatively is drawn in the interval between Samples 54-1, 146-148 cm and 53-1, 86-89 cm, the latter yielding, for the first time, rare specimens of Acarinina bullbrooki. In the interval from Sample 52-1, 123-126 cm to Sample 53-1, 86-89 $\mathrm{cm}$ planktonic foraminifers are sporadic; Acarinina bullbrooki, A. triplex, A. pentacamerata, and Globigerina sp. occur therein. From Sample 51-4, 58-62 cm to Sample 51-7, 8-11 cm they become more diverse and include Acarinina bullbrooki, $A$. triplex, A. pentacamerata, Globigerina boweri, $G$. pseudoeocaena, G. senni, Globorotalia frontosa, and $G$. aragonensis, which denote a middle Eocene age.
In Samples 51-3, 58-61 cm; 51-2, 120-122 cm; and 51-1, $45-48 \mathrm{~cm}$ rare Acarinina rotundimarginata were found; the age of these sediments is not older than the Globigerapsis kugleri Zone (likely close to the age of sediments transitional to the Globorotalia lehneri Zone). The interval from Sample 47-6, 122-126 cm to Sample 50-4, 104-105 cm contains rare specimens of Acarinina bullbrooki, A. sp., Globorotalia frontosa, Globigerapsis kugleri, G. index, Globigerina sp. Although these do not allow a specific age determination within the middle Eocene, it is possible that the interval contains, in addition to the upper part of the middle Eocene, some upper Eocene as well.

\section{Oligocene}

Oligocene deposits in the interval from Sample 45-5, 63-65 $\mathrm{cm}$ to Sample 47-2, 138-140 $\mathrm{cm}$ are characterized by poor associations of Globigerina prasaepis, $G$. officinalis, G. ouachitaensis, G. galavisi, and Globigerinita unicava. In the basal layers, reworked middle Eocene foraminifers were identified.

The Globorotalia opima Zone in the interval from Sample $43-5,20-22 \mathrm{~cm}$ to Sample $45-4,92-94 \mathrm{~cm}$, is readily distinguished despite the foraminifers being rare; it contains Globorotalia opima, G. nana, Globigerinita unicava, Globigerina venezuelana, G. praebulloides leroyi, $G$. ouachitaensis, and $G$. tripartita.

The same species, but without Globorotalia opima, are developed higher in the section in the interval from Sample $43-1,37-39 \mathrm{~cm}$ to Sample $43-4,27-31 \mathrm{~cm}$, indicating uppermost Oligocene.

The thickness of the Oligocene section is at least 60 meters; Oligocene and lower Miocene deposits are separated by an 18.5-meter interval in which there was poor core recovery (Cores 42 and 41 ). Siliceous sponge spicules are extremely abundant in the Oligocene sediments.

\section{Miocene}

The absence of such species as Globigerina ciperoensis and $G$. angulisuturalis in the upper Oligocene, and Globigerinoides primordius in the lower Miocene makes establishment of the Oligocene/Miocene boundary difficult. It is tentatively drawn below Sample $41-1,38-40 \mathrm{~cm}$, a foraminiferal assemblage of the Globigerinoides primordius-Globorotalia kugleri Zone is developed. This assemblage consists of Globorotalia kugleri, $G$. nana, $G$. siakensis, Globigerina venezuelana, $G$. praebulloides, $G$. juvenilis, G. woodi, Globigerinita stainforthi, G. unicava, G. dissimilis, and Globoquadrina aff. praedehiscens.

In the interval from Sample 39-1, 79-81 cm to Sample $32-2,58-60 \mathrm{~cm}$ the few specimens recovered testify only to belonging to sediments of lower Miocene age. Radiolarians and siliceous sponge spicules here are abundant.

Higher in the section (from Sample 37-1, 29-31 cm to Sample $38-1,68-70 \mathrm{~cm}$ ) the Globigerinita dissimilis Zone is clearly demarked. It contains Globigerinoides trilobus, $G$. altiaperturus, Globoquadrina praedehiscens, $G$. altispira, Globigerinita dissimilis, G. unicava, G. stainforthi, Globigerina juvenilis, G. bradyi, G. angustiumbilicata, $G$. venezuelana, Globorotalia siakensis, $G$. continuosa, and $G$. aff. peripheroronda . 
Overlying sediments in the interval from Sample 35-1, $70-72 \mathrm{~cm}$ to Sample $36-2,8-10 \mathrm{~cm}$ contain rare specimens of Globoratalia peripheronda, G. siakensis, Globoratalia altispira, Globigerina druryi, G. juvenilis, and Globigerinoides trilobus. The age of these sediments lies within the upper part of the lower Miocene (the Globigerinita stainforthi-Praeorbulina glomerosa zones) and the lowermost part of the middle Miocene (the Orbulina suturalis-Globorotalia peripheroronda Zone), if the section is continuous. The thickness of lower Miocene and, likely, middle Miocene basal layers is 57.5 meters.

Higher in the middle Miocene, the following zones, almost the entire succession, can be observed, from the base upward: the Globorotalia peripheroacuta Zone (Sample 34, CC) with the index species, $G$. siakensis, $G$. peripheroronda, $G$. continuosa, $G$. praemenardii, Orbulina suturalis, Globigerinoides trilobus, Globoquadrina dehiscens, G. altispira, and Sphaeroidinellopsis seminulina .

Core 33 yielded no recovery; this interval appears to correspond to the Globorotalia fohsi fohsi Zone.

The Globorotalia fohsi lobata Zone (from Sample 31-1, $138-140 \mathrm{~cm}$ to Sample $32-2,6-8 \mathrm{~cm}$ ) with an assemblage including the index species, $G$. fohsi fohsi, $G$. siakensis, $G$. continuosa, G. obesa, G. scitula, Orbulina suturalis, $O$. universa, Sphaeroidinellopsis seminulina, Globigerinella siphonifera, Globoquadrina dehiscens, G. altispira, Globigerina bollii, G. juvenilis, G. foliata, G. druryi, Globigerinoides trilobus, and Globigerinita glutinata.

The Sphaeroidinellopsis subdehiscens-Globigerina druryi Zone (Sample 30-1, 86-88 cm): its assemblage consists of numerous Globorotalia siakensis combined with rare Sphaeroidinellopsis subdehiscens, Globigerina juvenilis, G. druryi, Globigerinita glutinata, Globoquadrina dehiscens, Orbulina suturalis, and Globorotalia continuosa.

The Globigerina nepenthes-Globorotalia siakensis Zone (Sample 29-1, 145-147 cm) in which rare $G$. nepenthes and small Globorotalia menardii appear: other foraminifers are similar to those of the previous zone except $G$. druryi is absent.

The thickness of middle Miocene deposits is about 66 meters.

All upper Miocene zones have been distinguished but the poor specific composition of foraminifers (especially in the upper part of this age) prevents precise establishment of the boundaries.

The Globorotalia continuosa Zone (from Sample 25-3, $59-61 \mathrm{~cm}$ to Sample 28, CC) contains numerous $G$. continuosa associated with $\operatorname{rarer} G$. menardii (small forms), Globigerina nepenthes, G. bulloides, G. bollii, $G$. quinqueloba, Globigerinita glutinata, Orbulina universa, $O$. suturalis, Globoquadrina dehiscens, G. altispira, Sphaeroidinellopsis subdehiscens, and S. seminulina. No Globorotalia siakensis specimens were found here.

The Globorotalia merotumida Zone (from Sample 22-4, $80-82 \mathrm{~cm}$ to Sample $25-2,59-61 \mathrm{~cm}$ ) is characterized by the index species, $G$. acostaensis, $G$. menardii, $G$. lenguaensis, G. scitula, Orbulina universa, Globigerina bulloides, $G$. nepenthes, G. quinqueloba, Globoquadrina dehiscens, $G$. altispira, Sphaeroidinellopsis seminulina, $S$. subdehiscens, Globigerinita glutinata, G. uvula, Globigerinoides trilobus, and G. bollii.

Deposits in the interval from Sample 17-1, 25-27 cm to Sample 22-3, 80-82 cm should be attributed to the undifferentiated Globorotalia merotumida-Globorotalia pleisiotumida zones. In it planktonic foraminifers are rare and poorly preserved. They include Orbulina universa, Globigerina bulloides, $G$. nepenthes, $G$. quinqueloba, $G$. juvenilis, Globorotalia acostaensis, $G$. scitula, Sphaeroidinellopsis seminulina, S. subdehiscens, Globigerinita glutinata, G. uvula, and Globorotaloides hexagonus. In the upper part of this interval sporadic specimens of Neogloboquadrina dutertrei appear, suggesting the presence of the Globorotalia plesiotumida Zone.

The uppermost Miocene (from Sample 15-2, 84-86 cm to Sample 16-1, 63-65 cm) is capped with the Globorotalia margaritae margaritae Zone characterized by the index species, G. acostaensis, Neogloboquadrina dutertrei, Orbulina universa, Globigerina bulloides, Globigerinita glutinata, Globorotaloides hexagonus, Globigerinoides obliquus, and Sphaeroidinellopsis seminulina. Upper Miocene deposits are 122 meters thick. Total thickness of the entire Miocene is 245.5 meters.

\section{Pliocene}

As in case of the Miocene section, it is difficult to subdivide the Pliocene because many genera and species of planktonic foraminifers are absent as a result of selective dissolution. Only the Globorotalia margaritae evoluta Zone (from Sample 11-1, 95-97 cm to Sample 15-1, 114-116 cm) is reliably identified, with the index species, $G$. margaritae margaritae, $G$. puncticulata, $G$. crassaformis ronda, $G$. crassaformis oceanica, $G$. inflata, $G$. acostaensis, $G$. scitula, G. hirsuta, Orbulina universa, Globigerina bulloides, $G$. nepenthes, $G$. concinna, $G$. quinqueloba, $G$. megastoma, Neogloboquadrina dutertrei, Globorotaloides hexagonus, Globigerinita glutinata, $G$. uvula, Turborotalita iota, and sporadic specimens of Sphaeroidinellopsis subdehiscens, Globigerinoides sacculifer, G. trilobus, G. ruber, G. obliquus obliquus, and $G$. obliquus extremus. The top of the zone is drawn above Sample $11-1,95-97 \mathrm{~cm}$ in which the last rare specimens of Globorotalia margaritae evoluta were recognized, although disappearance of this species may have been caused by ecological or taphonomic factors.

In the interval from Sample 3-5, 92-94 cm to Sample $10-3,27-29 \mathrm{~cm}$ the specific composition of the fauna includes Globorotalia crassaformis s.1., G. inflata, $G$. scitula, Globigerina bulloides, $G$. concinna, $G$. megastoma, G. quinqueloba, Globigerinita uvula, $G$. glutinata, Orbulina universa, Globorotaloides hexagonus, Neogloboquadrina dutertrei, Turborotalita iota. Globigerinella siphonifera, Sphaeroidinella dehiscens, Globigerinoides sacculifer, G. pyramidalis, and G. trilobus are extremely rare. The interval corresponds to the Globorotalia miocenica and Globorotalia tosaensis zones. In Sample 4-5, $57-59 \mathrm{~cm}$ two small specimens of Globorotalia miocenica were identified, indicating that the interval from Sample 4-5, 57-59 cm to Sample 10-3, 27-29 $\mathrm{cm}$ involves the Globorotalia miocenica Zone. Such zones 
established by means of such rare findings hardly can be considered reliable.

The total recorded thickness of Pliocene deposits is 113 meters.

\section{Quaternary}

At Site 400 the thickness of Quaternary sediments is 96.5 meters, but cores were recovered only from the upper 9 meters and lower 22 meters of sediments of this interval. A similar circumstance occurred at Site 399, where the interval of 8 to 63 meters was penetrated without recovery. The zonal stratigraphy of the complete Quaternary section, the Globorotalia truncatulinoides Zone, is not possible in this area.

The Pliocene/Quaternary boundary was drawn beneath Sample 400A-3-2, 78-80 cm, where small specimens of Globorotalia truncatulinoides were recognized, but the boundary may be somewhat lower because the species is sporadical in the interval. It is completely absent in Samples 400A-3-1, 51-53 cm; 2-6, 33-35 cm; 2-5, 71-73 cm; 2-4, $91-93 \mathrm{~cm} ; 2-3,116-118 \mathrm{~cm} ; 2-1,78-80 \mathrm{~cm} ; 1, \mathrm{CC}$, and rare in Samples 400A-2-2, 90-92 cm and 1-1, 85-87 cm.

Quaternary sediments in the interval between Sample $400 \mathrm{~A}-1-1,85-87 \mathrm{~cm}$ and Sample 400A-3-2, 78-80 cm are characterized by numerous Globorotalia inflata, $G$. crassaformis crassaformis, $G$. crassaformis oceanica, $G$. scitula, Globigerina bulloides, $G$. concinna, $G$. quinqueloba, $G$. megastoma, $G$. quadrilatera, Globigerinita uvula, G. glutinata, Globorotaloides hexagonus, Orbulina universa, Globigerinella siphonifera, Turborotalita iota, and Neogloboquadrina dutertrei. N. pachyderma occurs in subordinate amounts. In Sample 2-3, 116-118 cm there are sporadic Globigerinoides conglobatus, and in Sample 1-1, 85-87 cm, occasional Globorotalia tosaensis. In some samples of Cores 400A-1 and 2, rare Globorotalia crassaformis hessi were recognized. As it can be seen the foraminiferal composition is impoverished. The ratio among Globorotalia inflata, $G$. crassaformis s.1., Globigerina bulloides, Orbulina universa, and Neogloboquadrina pachyderma in the samples studied noticeably varies, evidently reflecting climatic fluctuations. Sample 400 A-2-2, 90-92 cm is characterized by a higher content of Neogloboquadrina pachyderma. The sediments should be assigned to the Globorotalia crassaformis viola and Globorotalia crassaformis hessi sub-zones. The sediments and planktonic foraminifers of Core 2 in Hole 399 are of the same age.

The surface layer of the Quaternary sediments penetrated at Sites 399 and 400, the lower part is characterized by a poor, cold-water assemblage of planktonic foraminifers, Neogloboquadrina pachyderma being predominant among them. These sediments were formed under conditions of the late Pleistocene glaciation (from Samples 399-1-2, 85-87 $\mathrm{cm}$ to 399-1-6, 20-22 cm, and from Samples 400-1-3, 90-92 $\mathrm{cm}$ to $400-1-6,90-92 \mathrm{~cm})$.

The uppermost part of the Quaternary layer, 1.5 to 2.5 meters thick, contains a rich warm water (temperate) assemblage of planktonic foraminifers with common Globorotalia inflata, Neogloboquadrina dutertrei, Globigerina bulloides, G. megastoma, G. quadrilatera, $G$. quinqueloba, Globigerinita glutinata, Orbulina universa, and much less frequent Globorotalia truncatulinoides, $G$. crassaformis, G. scitula, G. bermudezi, G. cavernula, Globigerinoides ruber (pink and white), G. pyramidalis, Globigerina rubescens (pink and white), G. aff. calida calida, Globigerinella siphonifera, Globigerinita uvula, Turborotalita iota, and Neogloboquadrina pachyderma. This microfauna is peculiar to relatively warm climatic conditions of the postglaciation (Holocene).

\section{Site 401}

In this hole Cenozoic deposits, about 236.5 meters thick, were drilled with continuous coring, except for the interval from 9.5 meters down to 84.5 meters. The Cenozoic (Danian stage) is conformably underlain by the Upper Cretaceous Abathomphalus mayaroensis Zone (Maestrichtian). Unfortunately, due to poor recovery, the basal part of the Danian stage, containing minute thin-walled Globigerinas, was not recognized in this section. Speculatively, we may assume a hiatus here, but its length was negligible.

The Paleocene and lower Eocene section consists of yellowish and brown nannofossil chalk, nannofossilforaminiferal chalk and slightly argillaceous chalk. Middle and upper Eocene sediments are composed of greenish gray and light greenish nannofossil and nannofossil-foraminiferal chalk frequently enriched with radiolarians and sponge spicules. Above the 75-meter interval drilled without coring are Quaternary clayey calcareous oozes. A considerable part (possibly all) of the Oligocene and Neogene section is absent at Site 401.

The excellent fauna of planktonic foraminifers provides ready zonal subdivision of Paleocene and Eocene deposits.

\section{Paleocene}

The following zones have been identified in the Paleocene section: the Globorotalia trinidadensis Zone (from Sample 17-2, 60-63 cm to Sample 17-3, 8-10 cm) (Danian stage) with the index species, G. pseudobulloides, $G$. compressa, Globigerina triloculinoides, $G$. varianta, $G$. trivialis, G. daubjergensis, and Chiloguembelina midwayensis.

The Acarinina uncinata Zone (Sample 17-1, 118-120 cm) with the index species, $A$. spiralis, $A$. inconstans, $A$. sp., Globorotalia compressa, G. pseudobulloides, G. quadrata, Globigerina triloculinoides, and $G$. varianta.

The Globorotalia pseudomenardii Zone (from Sample $16-1,22-25 \mathrm{~cm}$ to Sample $16-3,15-18 \mathrm{~cm}$ ) with numerous specimens of the zonal species associated with $G$. velascoensis, $G$. laevigata, Acarinina mckannai, A. intermedia, Globigerina nana, and $G$. velascoensis. The section lacks deposits of the Globorotalia angulata Zone and, perhaps, the lower part of the Globorotalia pseudomenardii Zone.

The Globorotalia velascoensis Zone (from Sample 14-1, $129-132 \mathrm{~cm}$ to Sample $14-5,7-10 \mathrm{~cm}$ ) including the index species, G. acuta, G. aequa, G. hispidicidaris, Acarinina soldadoensis, $A$. acarinata, $A$. intermedia, $A$. primitiva, $A$. mckannai, Globigerina velascoensis, $G$. nana, $G$. quadritriloculinoides, and $G$. compressaformis. There was no recovery in Core 15. 
Thickness of the Paleocene section (including the Danian stage) is 38 meters.

\section{Eocene}

Eocene sediments are characterized by abundant, excellently preserved planktonic foraminifers.

The lower Eocene section at Site 401 comprises four zones:

The Globorotalia subbotinae Zone s.1. with numerous G. subbotinae, G. marginodentata, G. wilcoxensis, Acarinina pseudotopilensis, Globigerina eocaenica, $G$. compressaformis, with rarer Globorotalia formosa gracilis, $G$. aequa, $G$. aff. planoconica, Acarinina esnaensis, $A$. acarinata, A. soldadoensis, A. mckannai, Globigerina nana, and Pseudohastigerina wilcoxensis. It encompasses the interval from Sample 13-3, 27-30 cm to Sample 13-5, $43-45 \mathrm{~cm}$. The Globorotalia subbotinae Zone s.1. can be subdivided into two sub-zones: Globorotalia subbotinae s. str. with predominance of the index species and $G$. aequa (Sample 13-5, 43-45 cm) and the Globorotalia marginodentata Sub-zone where the index species and $G$. formosa gracilis are characteristic (Samples 13-4, 25-29 cm and $13-3,27-30 \mathrm{~cm}$ ).

The Globorotalia formosa Zone (from Sample 12-5, $55-57 \mathrm{~cm}$ to Sample 13-2, 50-53 cm) with numerous $G$. formosa formosa, $G$. lensiformis, Acarinina pseudotopilensis, Globigerina eocaenica accompanied by rarer Globorotalia formosa gracilis, G. marksi, $G$. marginodentata, Acarinina soldadoensis angulosa, A. interposita, A. triplex, A acarinata, A. broedermanni, and Pseudohastigerina wilcoxensis.

The Globorotalia aragonensis Zone (from Sample 12-1, $55-57 \mathrm{~cm}$ to Sample $12-4,55-57 \mathrm{~cm}$ ) containing numerous $G$. aragonensis, Acarinina interposita, A. pseudotopilensis and rarer Acarinina pentacamerata, A. triplex, $A$. broedermanni, Globorotalia planoconica, Globigerina pseudoeocaena, G. eocaenica, Pseudohastigerina wilcoxensis. Globorotalia caucasica and, in the lower part of the zone, $G$. formosa formosa, G. lensiformis, and Acarinina acarinita were observed as sporadic specimens. The lowest sample is characterized by transitional fauna from the Globorotalia formosa Zone into the Globorotalia aragonensis Zone.

The Globorotalia palmerae Zone (from Sample 11-4, $125-127 \mathrm{~cm}$ to Sample 11-5, 31-33 cm) with widely distributed Acarinina pentacamerata, A. interposita, A. aspensis, A. broedermanni, Globorotalia caucasica, Globigerina pseudoeocaena, and Pseudohastigerina wilcoxensis in combination with less numerous Globorotalia aragonensis, G. planoconica, Acarinina triplex, A. pseudotopilensis, Globigerina eocaenica, and $G$. eocaena.

The thickness of lower Eocene deposits is 24 meters.

The middle Eocene section includes the following zones:

The Hantkenina aragonensis Zone s.1. has a three-membered structure. The lower part (from Sample $11-1,124-126 \mathrm{~cm}$ to Sample $11-2,49-51 \mathrm{~cm})$ is characterized by the appearance of Acarinina bullbrooki, Globigerina boweri, and Pseudohastigerina micra, accompanied by numerous Globorotalia caucasica and common $G$. aragonensis, Acarinina aspensis, $A$. pentacamerata, A. triplex, Globigerina senni, G. higginsi, and $G$. pseudoeocaena. These are transitional layers from the lower to middle Eocene. Acarinina bullbrooki and Globigerina boweri are more numerous in the middle member of this zone (from Sample 10-2, 102-104 cm to Sample 10-7, 44-46 cm), where Globorotalia spinulosa, $G$. aff. pseudomayeri, Globigerina posttriloculinoides appear; Globorotalia caucasica and $G$. aragonensis are presented here by rare specimens. Other species include Acarinina triplex, A broedermanni, A pentacamerata, A aspensis, Globigerina higginsi, $G$. senni, $G$. eocaena, $G$. pseudoeocaena, and Pseudohastigerina micra. The upper member of the zone, the Hantkenina aragonensis Zone s.str. (from Sample 9-1, 93-96 cm to Sample 10-1, 108-110 $\mathrm{cm}$ ) is characterized by appearance of the index species, Globorotalia renzi, Globigerapsis aff. index, Truncorotaloides aff. rohri, and abundant Acarinina bullbrooki; Globigerina boweri is invariably present. Other species of planktonic foraminifers are the same as in the middle member of the zone, but Globorotalia caucasica, $G$. aragonensis, Acarinina pentacamerata, and A. triplex become rare. Thus, deposits of the Hantkenina aragonensis s.1. Zone are developed in the interval from Sample 9-1, 93-96 cm to Sample 11-2, 49-51 cm.

In the Globigerapsis kugleri Zone (from Sample 7-4, $117-119 \mathrm{~cm}$ to Sample 8-7, 67-69 $\mathrm{cm}$ ) there appears the index species, $G$. index, Globorotalia frontosa, Truncorotaloides topilensis, T. rohri and rare Acarinina rotundimarginata, Hantkenina liebusi, and $H$. lehneri. Accompanying species are represented by numerous Acarinina bullbrooki, Globigerina boweri, and Pseudohastigerina micra with less frequent Globorotalia spinulosa, G. renzi, $G$. aff. pseudomayeri, Acarinina aspensis, A. triplex, A. broedermanni, Globigerina senni, $G$. higginsi; $G$. pseudoeocaena, and $G$. posttriloculinoides. In sediments from Sample 8-5, 32-34 cm to Sample 8-7, 67-69 cm, Hantkenina aragonensis and Globigerapsis kugleri were not present, but numerous specimens of Globorotalia frontosa and rare Hantkenina liebusi were recognized. The latter circumstance allows us to attribute tentatively the sediments of this interval to the Globigerapsis kugleri Zone.

The Globorotalia lehneri Zone (from Sample 6-2, $137-139 \mathrm{~cm}$ to Sample 7-3, 118-120 cm) contains abundant Acarinina rotundimarginata, A. bullbrooki, Truncorotaloides rohri, T. topilensis and frequent Globigerapsis index, G. kugleri, Globorotalia frontosa, $G$. spinulosa, Globigerina pseudoeocaena, and $G$. pseudoeocaena compacta; Hantkenina liebusi and $H$. lehneri, though not numerous, are constantly present. Other species present are Pseudohastigerina micra and rare Globorotalia aff. pseudomayeri, Globigerina boweri, $G$. senni, and Acarinina aspensis. In the upper part of the zone Hantkenina alabamensis appears.

The Orbulinoides beckmanni Zone (from Sample 5-1, $119-121 \mathrm{~cm}$ to Sample 6-1, 89-92 cm) is characterized by the invariable presence of Hantkenina alabamensis, and the appearance of Globorotalia centralis and Globigerina pseudovenezuelana. Rather numerous are Globigerina pseudoeocaena pseudoeocaena, G. pseudoeocaena compacta, Globigerapsis index, Truncorotaloides rohri, 
and $T$. topilensis accompanied by less frequent Pseudohastigerina micra, Globorotalia frontosa, $G$. renzi, $G$. spinulosa, G. spinuloinflata, and Globigerinatheca barri. In the lower part of the zone there are frequent Acarinina bullbrooki and Acarinina rotundimarginata, but they are less numerous higher up in the section. In Sample 5-1, 119-121 cm sporadic Globorotalia lehneri and $G$. bolivariana were found.

The Truncorotaloides rohri Zone (Sample 4, CC) assemblage includes $T$. rohri, Globigerinatheca barri, Globigerapsis index, Globigerina galavisi, $G$. pseudovenezuelana, Globorotalia centralis, G. pomeroli, G. spinulosa, and Pseudohastigerina micra. Rare Globigerapsis tropicalis, Globorotalia cerroazulensis, and Globigerina angiporoides are present in the sediments of the upper part of the zone. It is quite possible that the Truncorotaloides rohri and the Orbulinoides beckmanni zones are separated by a hiatus, but poor core recovery in Core 4 makes the solution of this question difficult. The thickness of the middle Eocene section is 71 meters.

A limited number of samples permits a suggested outline of the zonal subdivision of the upper Eocene:

Undifferentiated Globigerapsis semiinvoluta and Globorotalia cocoaensis zones (Sample 3-1, 30-32 cm) with Globigerapsis tropicalis, Globorotalia centralis, Globigerina corpulenta, $G$. galavisi, $G$. tripartita, $G$. ouachitaensis, Pseudohastigerina micra, and $P$. barbadoensis.

The Globorotalia cocoaensis Zone (Sample 2, CC) contains broken specimens of Cribrohantkenina inflata, Globigerapsis tropicalis, Globigerina corpulenta, $G$. galavisi, G. angiporoides, G. praebulloides, and Pseudohastigerina micra.

The Globigerina gortanii-Globorotalia centralis Zone (Sample 2-1, 44-49 cm) contains a planktonic foraminiferal assemblage transitional from the upper Eocene to Oligocene and includes Globigerina corpulenta, $G$. angiporoides, $G$. galavisi, G. tripartita, G. praebulloides, G. prasaepis, Globorotalia permicra, G. gemma, Globigerinita unicava, Globorotaloides suteri, Pseudohastigerina micra, and $P$. barbadoensis. The thickness of the upper Eocene section is 19 meters and the total thickness of Eocene deposits at Site 401 is 114 meters.

\section{Quaternary}

Quaternary deposits, 9.5 meters thick, are subdivided into two parts. The lower (from Sample 1-3, 108-110 cm to Sample 1-6, 64-66 cm) is characterized by a poor assemblage where numerous Neogloboquadrina pachyderma are accompanied by rare $N$. dutertrei, Globorotaloides hexagonus, Globigerinita glutinata, Globigerina bulloides, G. quadrilatera, and Globorotalia inflata. The accumulation of sediments was proceeding under conditions of Pleistocene glaciation.

In the upper part (from Sample 1-1, 38-40 cm to Sample $1-2,108-110 \mathrm{~cm}$ ) the planktonic foraminifers are diverse with numerous Globorotalia inflata, Neogloboquadrina dutertrei, Globigerina bulloides accompanied by fewer Globorotalia truncatulinoides, $G$. crassaformis, $G$. hirsuta, Neogloboquadrina pachyderma, Globigerinoides ruber, Orbulina universa, Globigerina quadrilatera, $G$. megastoma, G. quinqueloba, Globigerinella siphonifera, and Globigerinita glutinata. This microfauna reflects relatively warm water conditions of Holocene postglaciation.

\section{Site $\mathbf{4 0 2}$}

At this site the Cenozoic section is incomplete and totals approximately 175 meters in thickness. The upper middle and upper Eocene deposits are composed of greenish gray and pale green nannofossil oozes and chalk, sometimes clayey, with a high content of siliceous organisms (radiolarians, diatoms, sponges). This part of the section at Site 402 significantly supplements Site 401 where the zonal subdivision of the upper middle Eocene part and the upper Eocene can be only outlined. In the interval from 89.5 meters down to 118 meters there was no core recovery, Higher in the section occur Quaternary yellowish, gray, and gray greenish clayey nannofossil and nannofossilforaminiferal oozes in which only three cores were taken.

The middle Eocene is represented by the Truncorotaloides rohri Zone (from Sample 402A-1-5, $65-68 \mathrm{~cm}$ to Sample $402 \mathrm{~A}-4-3,88-90 \mathrm{~cm}$ ). Its foraminiferal assemblage consists of $T$. rohri, Acarinina rugosoaculeata, Globigerina incretacea, $G$. azerbaijanica, $G$. galavisi, $G$. pseudovenezuelana, $G$. pseudocorpulenta, $G$. praebulloides, Globorotalia centralis, $G$. pomeroli, $G$. spinulosa, G. renzi, G. bolivariana, Pseudohastigerina micra, Globigerinita howei, Globigerapsis index, Globigerinatheca barri, and Guembelina sp.; Truncorotaloides topilensis, Hantkenina alabamensis, and Globorotalia lehneri occur as rare specimens. Globigerina pseudoeocaena pseudoeocaena and $G$. pseudoeocaena compacta are representative of the basal layers of the zone, Globigerapsis tropicalis being frequent in the upper part of the zone. The interval thickness is 32 meters.

The late Eocene Globigerapsis semiinvoluta Zone (from Sample 402-5-1, 123-126 cm to Sample 402-5-4, 33-36 cm and, stratigraphically lower, from Sample 402A-1-2, 28-30 $\mathrm{cm}$ to Sample $402 \mathrm{~A}-1-4,106-109 \mathrm{~cm}$ ) is well established. The zone is characterized by Globigerapsis tropicalis, $G$. index, Globigerinatheca sp., Globigerina corpulenta, $G$. galavisi, G. pseudovenezuelana, G. angiporoides, $G$. azerbaijanica, G. ouachitaensis, Pseudohastigerina micra, Globigerinita howei, Globorotalia centralis, and $G$. pomeroli; the index species and Globorotalia cerroazulensis occur as sporadic specimens. Small specimens of Acarinina aff. rugosoaculeata were identified in the lower part of the zone. In Core 402-4 a core-catcher sample was recovered; the sediments are of late Eocene age, but they have not been analyzed by us. Visible thickness of the upper Eocene deposits is 25 meters.

The interval from 89.5 down to 118 meters sub-bottom was penetrated without recovery. Washings from there yielded, in addition to Quaternary foraminifers, the late Miocene and early Pliocene species Globorotalia merotumida, G. plesiotumida, G. margaritae evoluta, Globoquadrina dehiscens, and $G$. altispira. Either they are reworked Quaternary sediments, or some upper Miocene and lower Pliocene layers are present at the bottom of the interval. In any case, it appears that Oligocene and Neogene 
deposits were almost completely destroyed by erosion at both Sites 401 and 402 .

In the 89.5 meters of Quaternary sediments, three cores were taken. The sediments in the interval 42.0 to 89.5 meters (Samples 2-1, 18-20 cm and 3-1, 88-90 cm) contain the rather diverse assemblage of Globorotalia truncatulinoides, $G$. inflata, $G$. crassaformis, $G$. hirsuta, Neogloboquadrina dutertrei, Orbulina universa, Globigerinoides ruber, Globigerina bulloides, $G$. megastoma, and $G$. quinqueloba; specimens of Neogloboquadrina pachyderma are rare. In Sample 1-2, $113-115 \mathrm{~cm}$ planktonic foraminifers are compositionally poor, $N$. pachyderma being predominant; these sediments correspond to the time of Pleistocene glaciation. In the uppermost layer of sediments (Sample 1-1, 24-26 cm) the foraminifers are again diverse and abundant and include Globorotalia truncatulinoides, G. inflata, Orbulina universa, Neogloboquadrina dutertrei, Globigerina bulloides, G. megastoma, G. quadrilatera, Globigerinoides ruber, etc.; they are relatively warm water postglacial species, Neogloboquadrina pachyderma is in subordinate amounts.

\section{Rockall Plateau}

Near the southwestern margin of Rockall Plateau the drilling was carried out in two regions: at the rifted margin of the plateau, roughly 30 kilometers east of the oldest magnetic anomaly (24) recorded in the adjacent ocean crust (Sites 403 and 404) and south of the transform fault which defines the southwestern margin of the plateau (Sites 405 and 406). Cenozoic stratigraphy at these four sites has much in common.

\section{Site $\mathbf{4 0 3}$}

The character of Cenozoic deposits at Site 403 is considerably varied. At the base of the section Paleocene-lower Eocene medium- and coarse-grained arkosic sandstones with interbeds of lignitic mudstones and tuffaceous siltstones occur. They are overlain by lapilli conglomerates, tuffs, tuffaceous mudstones, and mudstones also of the early Eocene age. The thickness of these terrigenous-volcanic deposits is 229 meters. Above them lie 37 meters of nannofossil and nannofossil-foraminiferal chalk of the early Eocene, middle Eocene, and Oligocene age, being separated by unconformities. The Oligocene sediments are overlain by 223 meters of nannofossil and nannofossil-foraminiferal chalk and oozes of late Miocene to Quaternary age. Late Pliocene-Quaternary oozes contain clay and ice-rafted pebbles and grains.

\section{Paleogene}

Sediments at the base of the section (Cores 52 to 45 ) are devoid of organic remains; sporadic, poorly preserved benthic foraminifers (Eponides, Valvulineria, Cibicides, Robulus) and mollusk fragments appear in Cores 44, 43, and 42. These deposits are tentatively attributed to the Paleocene.

In Cores 41 to 39 benthic foraminifers are, as previously, sporadic, but their composition is somewhat more diverse (Cibicides, Valvulineria, Nodosaria, Robulus, Lagena, Gyroidina, Alabamina, Pseudopolymorphina). In Sample
41-1, 136-138 cm rare Globigerina sp. are present, and ostracodes appear.

Cores 38 to 29 also contain rare benthic foraminifers; in some samples they are completely absent. In Samples 38-4, $59-61 \mathrm{~cm} ; 38-2,77-81 \mathrm{~cm} ; 38-1,62-66 \mathrm{~cm} ; 37-3,106-110$ $\mathrm{cm} ; 37-1,107-110 \mathrm{~cm}$; and $29-1,26-28 \mathrm{~cm}$, although not numerous, they are diverse: Anomalina, Cibicides, Eponides, Gyroidina, Valvulineria, Alabamina, Bulimina, Quinqueloculina, Glandulina, Pullenia, Robulus, Lenticulina, Marginulina, Nodosaria, Lagena, Dentalina, Textularia. Planktonic foraminifers are extremely rare: Globigerina nana in Sample 38-4, 59-61 cm; Globigerina sp. and Acarinina sp. in Sample 29-1, 26-28 cm. Sediments in this interval show a general increase of diversity in organic remains; common are needles of sea urchins, bryozoa, ostracodes, and fragments of mollusks. On the basis of nannoplankton, the deposits are of early Eocene age (see Müller, this volume).

The first good assemblage of planktonic foraminifers was found in Sample 28-1, 25-27 cm. It contains rare small Globigerina eocaenica, G. nana, G. sp., Acarinina pseudotopilensis, A acarinata, A. esnaensis, A . primitiva, and $A$. sp. denoting an early Eocene age.

Sample $26-4,12-15 \mathrm{~cm}$ is characterized by planktonic foraminifers of the upper middle Eocene, with numerous, but small Globigerina pseudoeocaena, and $G$. sp. in combination with rare Acarinina rotundimarginata, $A$. sp., and Globorotalia centralis.

In the interval from Sample 26-3, $37-39 \mathrm{~cm}$ up to $26-1$, $32-34 \mathrm{~cm}$ Oligocene planktonic foraminifers are numerous and rather diverse, the fauna comprising Globorotalia opima, G. nana, Globigerina prasaepis, G. ouachitaensis, G. galavisi, G. angustiumbilicata, G. pseudovenezuelana, Globorotaloides suteri, and Globigerinita unicava (the Globorotalia opima Zone).

\section{Upper Miocene}

The upper Miocene section, 114 meters thick, begins with sediments containing the Globorotalia merotumida Zone (from Sample 23-1, 55-57 cm to Sample 25-1, 3-5 $\mathrm{cm}$ ). Its assemblage consists of enormous accumulations of Globorotalia acostaensis combined with lesser $G$. miozea miozea, G. miozea cibaoensis, G. globorotaloidea, Globigerina bulloides, G. microstoma, G. quinqueloba, Orbulina universa, and Globoquadrina dehiscens; sporadic specimens of Globorotalia merotumida, $G$. menardii, $G$. cultrata, G. scitula, Globigerina nepenthes, G. juvenilis, Globigerinoides bollii, and Sphaeroidinellopsis seminulina are present.

The Globorotalia plesiotumida Zone (from Sample 16-2, $120-122 \mathrm{~cm}$ to Sample 22-6, 62-64 cm) has numerous $G$. conomiozea, G. miozea conoidea, G. pseudomiocenica and rare small $G$. aff. plesiotumida. $G$. acostaensis, $G$. globorotaloidea, Globigerina bulloides, $G$. concinna, $G$. quinqueloba, Globigerinita glutinata, and G. uvula continue to be numerous, accompanied by rare Globorotalia scitula, Orbulina universa, Globigerina falconensis, $G$. nepenthes, G. decoraperta, and Sphaeroidinellopsis subdehiscens.

The Globorotalia margaritae margaritae Zone (from Sample $13-1,54-57 \mathrm{~cm}$ to Sample $14-2,38-40 \mathrm{~cm}$ ) is 
characterized by common specimens of $G$. margaritae primitiva and $G$. margaritae margaritae. Widely distributed are Globigerina bulloides, G. concinna, G. quinqueloba, Orbulina universa, Globorotalia acostaensis, and $G$. globorotaloidea accompanied by fewer Globorotalia scitula, Globigerina decoraperta, Globigerinita glutinata, and $G$. uvula.

\section{Pliocene}

The Globorotalia margaritae evoluta Zone (from Sample 9-1, 95-97 cm to Sample 12-6, 106-108 cm) is clearly distinguishable. It is marked by the appearance of the index species accompanied by numerous Globorotalia puncticulata, G. crassaformis ronda, G. crassaformis oceanica, and rare $G$. inflata; $G$. margaritae margaritae and Globoquadrina dehiscens are still present. Other foraminifers are abundant: Globigerina bulloides, $G$. concinna, G. quinqueloba, Globigerinita glutinata, Globorotalia acostaensis, G. globorotaloidea and rarer Globorotalia humerosa, G. scitula, G. miozea conoidea, Neogloboquadrina dutertrei, Globigerinella siphonifera, Orbulina universa, Globigerina decoraperta, $G$. atlantica, and $G$. foliata.

Among the sediments in this interval are chalk clasts of older (upper Miocene) age. In some samples planktonic foraminifers display distinct traces of sorting, and the sediment is regarded as being a calcareous turbidite.

The overlying Pliocene sediments contain the undifferentiated Globorotalia miocenica-Globorotalia tosaensis zones, and are characterized by Globorotalia puncticulata, $G$. acostaensis, $G$. humerosa, $G$. globorotaloidea, $G$. scitula, $G$. inflata, $G$. crassula, $G$. crassaformis (varieties - crassaformis, ronda, oceanica), Globigerina bulloides, $G$. concinna, $G$. quinqueloba, $G$. decoraperta, G. falconensis, Neogloboquadrina dutertrei, Orbulina universa, Globigerinella siphonifera, Globigerinita uvula, and G. glutinata. The interval is divisible into two parts: (1) (from Sample 7-1, 128-130 cm to Sample 8-6, 101-103 cm) layers with abundant specimens of $G$. crassaformis crassaformis, $G$. crassaformis oceanica, and $G$. crassaformis ronda and rare specimens of $G$. inflata; (2) (from Sample 5-1, 55-57 cm to Sample 5-5, 108-110 cm) layers with numerous Globorotalia inflata, and rare to absent $G$. crassaformis s.1.

Total thickness of Pliocene deposits is 81 meters.

\section{Quaternary}

The exact sub-bottom position of the Pliocene-Quaternary boundary has not been established because of poor recovery in Core 4 and the impoverished specific composition of planktonic foraminifers. Sample $4-1,90-92 \mathrm{~cm}$ is characterized by numerous Globorotalia inflata, G. crassaformis crassaformis, Globigerina bulloides, $G$. concinna, and $G$. quinqueloba with rarer Globorotalia scitula, Neogloboquadrina dutertrei, Orbulina universa, Globigerina decoraperta, and Globigerina glutinata. Presence of infrequent Globorotalia crassaformis viola shows that the age of the sediments is confined to the late Pliocene (the Globorotalia tosaensis Zone) - early Quaternary (the Globorotalia crassaformis viola Sub-zone). The Pliocene/Pleistocene boundary is likely to be within Core 4. Sample 3-3, 47-49 cm contains Globorotalia truncatulinoides and G. crassaformis hessi, and corresponds stratigraphically to higher layers of the Pleistocene (the Globorotalia crassaformis hessi Sub-zone).

Almost all typical species are found throughout the Quaternary sediments, i.e., Globorotalia truncatulinoides, $G$. inflata, $G$. acostaensis, $G$. scitula, G. hirsuta, $G$. crassaformis (crassaformis, ronda), G. crassula crassula, $G$. crassula viola, Neogloboquadrina pachyderma, $N$. dutertrei, Globigerina bulloides, G. concinna, $G$. quinqueloba, G. microstoma, Orbulina universa, Globigerinella siphonifera, Globigerinita glutinata, $G$. uvula, and Turborotalita iota. Only Globorotalia crassaformis hessi disappears in the middle Quaternary. However, the ratio of the major species in the faunas varies rather strongly, probably reflecting climatic fluctuations of the Quaternary time:

1) layers with numerous Globorotalia inflata, $G$. crassaformis hessi, Globigerina bulloides, G. quinqueloba, Orbulina universa and rare Neogloboquadrina pachyderma (Sample 3-3, 47-49 cm);

2) layers with the same foraminifers, but with numerous N. pachyderma (from Sample 2-6, 29-31 cm to Sample 3-2, $48-50 \mathrm{~cm})$; Globorotalia crassaformis hessi was not recorded higher in the section;

3) layers with numerous Globorotalia crassaformis crassaformis, G. inflata, Globigerina bulloides, and rare Neogloboquadrina pachyderma (from Sample 2-4, 53-55 $\mathrm{cm}$ to Sample 2-5, 30-32 cm);

4) layers with abundant $N$. pachyderma, Globigerina bulloides, G. quinqueloba, and Globorotalia inflata (Sample 2-3, 20-22 cm);

5) layers with rare Neogloboquadrina pachyderma and various other planktonic foraminifers, including Globigerinoides ruber (from Sample 2-1, 24-26 cm to Sample 2-2, 119-121 cm);

6) layers with predominant Neogloboquadrina pachyderma, and other diverse species of planktonic foraminifers (from Sample 1-3, 57-59 $\mathrm{cm}$ to Sample 1-4, $13-15 \mathrm{~cm})$;

7) layers with enormous amounts of $N$. pachyderma and rare other foraminifers (Sample 1-2, 27-29 cm).

The total thickness of Quaternary sediments is about 28 meters.

\section{Site 404}

Because Site 404 is within 5 kilometers of Site 403, the Cenozoic stratigraphy of the two sites has much in common. The section at Site 404 commences with tuffaceous conglomerates, glauconitic sandstones, and tuffitic mudstones with rare interbeds of arenaceous limestones (Paleocene?-lower Eocene). There follows a unit of lower Eocene glauconitic and siliceous limestones, tuffs, and glauconitic mudstones, capped by silicified limestones and porcellanites with abundant radiolarians and sponge spicules. They in turn are overlain by nannofossil and nannofossil-foraminiferal oozes of the upper MioceneQuaternary. In the Quaternary part the oozes contain vitric tuffs, ice-rafted pebbles, and grains. In contrast to Site 403, there are no middle Eocene and Oligocene deposits at Site 404. 


\section{Paleogene}

In basal layers of the terrigenous-tuffaceous succession (Cores 25 and 24) no fauna was found. Higher up (Cores 23-19) appear sporadic benthic foraminifers such as Nonion, Nonionella, Cibicides, Discorbis, Valvulineria, Alabamina, Lenticulina, Nodosaria, Textularia, Polymorphina, ostracodes, bryozoa, and echinoid remains. The diversity and abundance of benthic foraminifers increases upwards (Cores 18-10): Cibicides, Anomalina, Glandulina, Lenticulina, Lagena, Marginulina, Nodosaria, Alabamina, Nonion, Siphonina, Eponides, Gyroidina, Reussella, Bolivina, Discorbis, Valvulineria, Pullenia, Bulimina, Uvigerina; radiolarians, diatoms, and sponges appear here as well. Within this interval occur the first sporadic Globigerina sp. (Samples 17-2, 66-69 $\mathrm{cm}$ and $17-1,82-84 \mathrm{~cm})$. Sample 16-1, 32-34 cm contains numerous minute Globigerina eocaenica, $G$. prolata, $G$. nana, $G$. sp., Acarinina triplex, and $A$. sp. (the lowermost Eocene). Samples 14-1, 1-3 cm and 10-1, 59-63 cm contain numerous Globigerina collactea, G. eocaenica, G. prolata, $G$. turgida, and Acarinina pseudotopilensis indicating that this interval is probably the upper part of the lower Eocene. Within silicified limestone (Samples 7-3, 55-58 cm and 7-2, $70-74 \mathrm{~cm}$ ), associated with a mass of radiolarians and sponges, rare planktonic foraminifers were found, including Acarinina pentacamerata, $A$. interposita, $A$. pseudotopilensis, and Globigerina pseudoeocaena testifying to the belonging of sediments to the upper part of the lower Eocene.

Thickness of the Paleogene deposits at Site 404 is 190 meters.

\section{Upper Miocene}

Two zones were recognized in sediments of this age:

The Globorotalia merotumida Zone (from Sample 5-1, $107-109 \mathrm{~cm}$ to Sample 6-1, $89-92 \mathrm{~cm}$ ) with numerous Globorotalia acostaensis, G. miozea miozea, G. miozea cibaoensis, Globigerina bulloides, $G$. decoraperta, $G$. concinna, G. quinqueloba, rare $G$. scitula, Orbulina universa, O. suturalis, Globoquadrina dehiscens, $G$. altispira, Globigerina foliata, Globigerinita glutinata, and sporadic Biorbulina bilobata, Globorotalia menardii, $G$. obesa, G. globorotaloidea, Sphaeroidinellopsis seminulina, and S. subdehiscens; and the Globorotalia plesiotumida Zone (from Sample 3-1, 83-86 cm to Sample 4-2, 23-26 $\mathrm{cm}$ ) where appear $G$. miozea conoidea, $G$. conomiozea, $G$. pseudomiocenica, rare $G$. plesiotumida, accompanied by $G$. acostaensis, G. globorotaloidea, G. scitula, G. humerosa, Globigerina bulloides, G. concinna, G. quinqueloba, $G$. foliata, $G$. decoraperta, $G$. nepenthes, Orbulina universa, Globigerinita glutinata, Globoquadrina dehiscens, Sphaeroidinellopsis seminulina, and $S$. subdehiscens.

The apparent thickness of the upper Miocene is 95 meters.

In the interval from 28 meters down to 104 meters there was no core recovery. The sediments of this interval most likely correspond to the uppermost Miocene and the Pliocene.

\section{Quaternary}

In Quaternary sediments, 28 meters thick, only two cores were obtained, at the base and top of the section; in the interval from 9 meters down to 21.5 meters no cores were recovered. Variations of the specific composition of planktonic foraminifers reflect climatic fluctuations of the Quaternary time:

1) a relatively cold-water assemblage with abundant Neogloboquadrina pachyderma, common Globorotalia inflata, G. crassaformis, Globigerina bulloides, $G$. concinna, G. quinqueloba, and sporadic Globorotalia truncatulinoides, etc. (Sample 2-6, 34-36 cm);

2) a warm-water assemblage with various foraminifers including Globorotalia crassaformis hessi, $G$. truncatulinoides, G. hirsuta, Orbulina universa, etc.; Neogloboquadrina pachyderma are rare, and in some samples, practically absent (from Sample 2-1, 82-84 cm to Sample 2-6, 34-36 cm).

Especially frequent are variations in the foraminiferal composition in the surface 9 meters.

3) layers with Neogloboquadrina pachyderma and Globigerina bulloides, where other species are in subordinate amounts (Sample 1-6, 104-106 cm);

4) layers with abundant Globigerina bulloides and $G$. quinqueloba where Globorotalia inflata and Neogloboquadrina pachyderma are not numerous (Sample $1-5,61-63 \mathrm{~cm})$;

5) layers with enormous numbers of Neogloboquadrina pachyderma, but rare Globigerina bulloides, $G$. quinqueloba, Orbulina universa, Globorotalia inflata, and G. crassaformis (Sample 1-4, 129-131 cm);

6) layers with diverse foraminifers where Globigerina bulloides, G. concinna, G. quinqueloba, and Globorotalia inflata are predominant, and Neogloboquadrina pachyderma are in subordinate amounts (Sample 1-3, 129-131 cm);

7) layers with an enormous mass of $N$. pachyderma and Globigerina bulloides but other species are not numerous (from Sample 1-1, $42-44 \mathrm{~cm}$ to Sample 1-2, 13-15 cm).

Holocene (postglacial) sediments are absent at Sites 404 and 403 .

\section{Site 405}

This hole penetrated a stratigraphically incomplete section of Cenozoic sediments, 407 meters thick.

\section{Eocene}

The section begins with a thick accumulation $(307 \mathrm{~m})$ of gray and greenish calcareous mudstones and silicified mudstones with some cherty interbeds. These sediments (from Sample 12-1, 136-138 cm to Sample 43-7, 4-6 cm) contain abundant remains of organisms with a siliceous skeleton (radiolarians, sponges, and, less frequently, diatoms). Planktonic foraminifers are not numerous and include Acarinina triplex, A. pentacamerata, $A$. interposita, A. pseudotopilensis, A. aff. aspensis, Globorotalia planoconica, Pseudohastigerina wilcoxensis, Globigerina eocaenica, $G$. turgida, and $G$. aff. 
pseudoeocaena. The sediments belong to the upper part of the lower Eocene, within the Globorotalia aragonensis and Globorotalia palmerae zones. Many samples are devoid of planktonic foraminifers.

Higher, there is a unit (35 m thick) of yellowish gray nannofossil and nannofossil foraminiferal chalk with some interbeds of silicified chalk (from Sample 8-1, 118-120 cm to Sample 11-1, 16-18 cm). Radiolarians and sponges are abundant in some layers only. The variety of planktonic foraminifers is diverse, their numbers increasing upwards in the section. Included are Acarinina bullbrooki, A. aspensis, A. pentacamerata, A. triplex, Globigerina boweri, $G$. senni, G. posttriloculinoides, G. pseudoeocaena, $G$. eocaena, Pseudohastigerina micra, Globorotalia bolivariana, $G$. caucasica, and $G$. aragonensis, which are indicative of the basal part of the middle Eocene, most likely the lower part of the Hantkenina aragonensis Zone s.1., below the level of appearance of $H$. aragonensis itself (see Site 401).

\section{Upper Miocene}

Middle Eocene basal layers are overlain unconformably by bluish white nannofossil ooze belonging to the uppermost Miocene Globorotalia margaritae margaritae Zone (from Sample 6-1, 144-147 cm to Sample 7-1, $30-32 \mathrm{~cm})$. Planktonic foraminifers present are $G$. margaritae margaritae, G. acostaensis, G. scitula, G. globorotaloidea, Globigerina bulloides, G. concinna, G. quinqueloba, Orbulina universa, Sphaeroidinellopsis subdehiscens, and Globigerinita glutinata. The thickness of this zone is 19 meters.

\section{Quaternary}

Quaternary greenish gray and pale gray nannofossil and nannofossil-foraminiferal oozes unconformably overlie upper Miocene sediments, their thickness being 46 meters. The oozes contain unsorted pebbles and grains of various petrographic composition (ice-rafted material).

The Globorotalia truncatulinoides Zone is characterized by the index species, $G$. inflata, $G$. crassaformis, $G$. acostaensis, G. humerosa, G. scitula, G. crassula, Globigerina bulloides, G. concinna, G. quinqueloba, Globigerinita glutinata, Orbulina universa, Globigerinella siphonifera, and Neogloboquadrina pachyderma. The main components of planktonic foraminiferal assemblages occur in various ratios, reflecting the variations of Pleistocene climatic conditions. From base up:

1) a relatively warm water assemblage with diverse foraminifers with predominant Globigerina bulloides, $G$. concinna, $G$. quinqueloba, Globorotalia inflata and rare specimens of Neogloboquadrina pachyderma (from Sample 4-1, 128-130 cm to Sample 5-4, 31-33 cm);

2) a relatively cold water assemblage, poor by specific composition containing equal numbers of Neogloboquadrina pachyderma, Globorotalia inflata, and Globigerina bulloides (Sample 3-3, 43-45 cm);

3) a temperate water assemblage with numerous Globorotalia inflata, Globigerina bulloides, G. concinna; Neogloboquadrina pachyderma remains common (Sample 3-2, $57-59 \mathrm{~cm})$;
4) a relatively warm water assemblage with abundant Globorotalia inflata, Globigerina bulloides, G. concinna, G. quinqueloba, common Orbulina universa, less frequent Globorotalia crassaformis, and G. scitula and sporadic Globigerinoides ruber appear. Specimens of Neogloboquadrina pachyderma are not numerous (from Sample 2-5, 142-144 cm to Sample 3-1, 83-85 cm);

5) a relatively cold water assemblage with nearly equal amounts of Neogloboquadrina pachyderma, Globorotalia inflata, Globigerina bulloides, and G. concinna (Sample 2-4, 41-43 cm);

6) a cold water, almost monospecific assemblage consisting of many Neogloboquadrina pachyderma (Sample 2-3, 108-110 cm);

7) a relatively warm water assemblage with Globorotalia inflata, G. crassaformis, G. acostaensis, Globigerina bulloides, $G$. concinna, and $G$. quinqueloba; Neogloboquadrina pachyderma is present in subordinate amounts (from Sample 1-4, 130-132 cm to Sample 2-2, $133-135 \mathrm{~cm})$;

8) a relatively cold water assemblage with abundant Neogloboquadrina pachyderma, but Globorotalia inflata and Globigerina bulloides are also common (Sample 1-3, $131-133 \mathrm{~cm})$;

9) a relatively warm water assemblage with abundant Globorotalia inflata, Globigerina bulloides, G. concinna, frequent Orbulina universa, Globorotalia acostaensis, G. crassaformis, G. scitula, and sporadic Globigerinoides ruber; Neogloboquadrina pachyderma are in subordinate amounts (from Sample 1-1, 115-118 cm to Sample 1-2, $12-14 \mathrm{~cm})$.

\section{Site 406}

At Site 406, 841 meters of Cenozoic sediments were penetrated. The section begins with gray calcareous middle Eocene claystones, 66 meters thick, unconformably overlain by 93 meters of upper Eocene pale gray limestones and nannofossil chalk frequently enriched in radiolarians, sponge spicules, and passing into silicified limestones. Unconformably above these are 59 meters of pale gray nannofossil and nannofossil-foraminiferal Oligocene chalk. The upper Oligocene to lower Miocene beds, 56 meters thick, are greenish and yellowish, calcareous diatomites and chalk with enormous accumulations of siliceous organisms. A thick pile $(557 \mathrm{~m})$ of upper lower Miocene/Quaternary white and pale gray nannofossil oozes and chalk with some interbeds of nannofossil-foraminiferal oozes and chalk cap the section.

\section{Paleogene}

The basal middle Eocene layers contain abundant Pseudohastigerina micra and less numerous Acarinina bullbrooki, A. pentacamerata, A. sp., Globigerina pseudoeocaena, G. postriloculinoides, and $G$. sp. The sediments (from Sample $46-2,7-9 \mathrm{~cm}$ to Sample 50-1, 4-5 cm) most probably belong to the lower part of the Hantkenina aragonensis s.1. Zone.

Upper Eocene deposits (from Sample 36-2, 33-36 cm to Sample $45-5,2-5 \mathrm{~cm}$ ) contain rich assemblages of Globigerina corpulenta, G. angiporoides, G. galavisi, G. 
pseudovenezuelana, G. praebulloides, G. ouachitaensis, $G$. azerbaijanica, Globigerapsis tropicalis, $G$. index, Globigerinatheca aff. barri, G. sp., Globorotaloides suteri, Globorotalia centralis, G. pomeroli, and Chiloguembelina sp. Sporadic Truncorotaloides rohri, $T$. topilensis, and Globigerinita howei were recognized in basal layers (Sample 45-5, 2-5 cm). The lowermost deposits can be attributed to the undifferentiated Globigerapsis semi-involuta and Globorotalia cocoaensis zones. Where radiolarians and sponge spicules are abundant, the number of planktonic foraminifers abruptly decreases. In the mixed associations of foraminiferal assemblages either Globigerina or Globigerapsis predominates.

Lower Oligocene beds are absent. The overlying Oligocene sediments are subdivided into two zones: the Globorotalia opima Zone (from Sample 33-1, 133-135 cm to Sample 36-1, 36-39 cm) with abundant specimens of the index species and Globorotaloides suteri; they are accompanied by fewer Globorotalia nana, $G$. sp., Globigerina prasaepis, $G$. praebulloides, $G$. angustiumbilicata, $G$. officinalis, $G$. tripartita, $G$. aff. venezuelana, and $G$. aff. sellii; the Globigerina ciperoensis Zone (from Sample 29-5, 7-10 cm to Sample 32-5, 68-71 $\mathrm{cm}$ ) follows with Globorotalia pseudokugleri, G. nana, Globorotaloides suteri, Globigerina praebulloides, $G$. tripartita, G. venezuelana, G. ouachitaensis, $G$. angustiumbilicata, G. brevispira, Globigerinita unicava, G. dissimilis, and G. stainforthi praestainforthi. The key species of this zone, Globigerina ciperoensis and $G$. angulisuturalis, are missing and the age of the sediments is based on the assumption of the disappearance of Globorotalia opima and appearance of G. pseudokugleri.

\section{Miocene}

It is not possible to draw the Oligocene/Miocene boundary by means of planktonic foraminifers. In the diatomites and diatom chalk of this interval (from Sample $25-1,110-112 \mathrm{~cm}$ to Sample 29-3, 98-102 cm), they are rare and poor in systematic composition; the fauna consists of Globigerina venezuelana, G.praebulloides, $G$. tripartita, Globigerinita stainforthi praestainforthi, G. dissimilis, G. unicava, Globoquadrina praedehiscens, and Globorotalia siakensis and is attributable to the undifferentiated upper Oligocene-lowermost Miocene.

Definitive lower Miocene begins with the uppermost part, the Praeorbulina glomerosa Zone (from Sample 20-3, $84-87 \mathrm{~cm}$ to Sample 24-1, 133-137 cm). Its foraminiferal assemblage consists of $P$. glomerosa, $P$. transitoria, Globigerinoides bisphaerica $G$. trilobus, $G$. subquadratus, Globorotalia siakensis, G. peripheroronda, G. scitula praescitula, G. minima, G. minutissima, G. obesa, Globigerina bollii, G. foliata, G. falconensis, $G$. juvenilis, $G$. bulbosa, Globigerinita naparimaensis, Globoquadrina dehiscens, G. altispira, and Sphaeroidinellopsis seminulina. The usual distribution of the key species occurs with Globigerinoides bisphaerica and Praeorbulina transitoria first appearing, to be joined in the upper half of the zone by Praeorbulina glomerosa with the varieties curva, glomerosa, circularis.
The base of the middle Miocene is clearly fixed by the Orbulina suturalis-Globorotalia peripheroronda Zone (Interval from Sample 20-1, 34-37 cm to Sample 20-2, $129-133 \mathrm{~cm})$, where these species are accompanied by Globorotalia siakensis, G. scitula praescitula, G. miozea miozea, Biorbulina bilobata, Praeorbulina glomerosa glomerosa, P. glomerosa circularis, P. transitoria, Globoquadrina dehiscens, Globigerina juvenilis, G. bollii, G. foliata, G. falconensis, Globigerinoides trilobus, and Sphaeroidinellopsis seminulina.

In the overlying middle Miocene sediments (from Sample $16-1,52-55 \mathrm{~cm}$ to Sample 19-1, 27-30 cm) Praeorbulina disappears and Globorotalia praemenardii appears. The latter is accompanied by $G$. siakensis, $G$. peripheroronda, G. miozea miozea, G. obesa, G. scitula scitula, G. scitula gigantea, Orbulina suturalis, Globigerina juvenilis, G. foliata, G. praebulloides, Globigerinoides trilobus, G. subquadratus, Globoquadrina dehiscens, and Sphaeroidinellopsis seminulina. The upper part of these layers is marked by Orbulina universa and Globorotalia aff. fohsi fohsi. The basal layers can be attributed to the Globorotalia peripheroacuta Zone, although the zonal species itself is absent. The complete absence of species of the Globorotalia fohsi group prevents detailed subdivision of the interval but the upper age limit of these middle Miocene deposits is determined at the level of the disappearance of Globorotalia praemenardii, i.e., the top of the Sphaeroidinellopsis subdehiscens-Globigerina druryi Zone.

The middle/upper Miocene boundary is clearly marked with an unconformity.

The following zones are distinguished in the upper Miocene succession: the Globorotalia continuosa Zone with the index species, Globorotalia miozea miozea, G. scitula, Globigerina bulloides, Orbulina universa, O. suturalis, and rare specimens of Globorotalia acostaensis. Possibly the sediments in this interval (Sample 15-2, 113-115 cm) should be placed in the base of the next zone which is the Globorotalia merotumida Zone (from Sample 9-1, $140-142 \mathrm{~cm}$ to Sample 15-1, 119-121 cm). Its assemblage consists of abundant Globorotalia acostaensis, common $G$. globorotaloidea, G. scitula, G. miozea miozea, G. miozea cibaoensis, Globigerina bulloides, G. concinna, $G$. juvenilis, G. quinqueloba, Orbulina universa, Globigerinita glutinata, G. uvula and still rarer Globorotalia merotumida, G. lenguaensis, Globoquadrina dehiscens, G. altispira, Globigerinoides trilobus, $G$. obliquus obliquus, Globigerina nepenthes, G. microstoma, G. decoraperta, Sphaeroidinellopsis seminulina, and $S$. subdehiscens.

The Globorotalia plesiotumida Zone follows (from Sample 6-1, 101-104 cm to Sample 8-7, 3-5 cm) with rare specimens of the index species and common $G$. miozea conoidea, G. conomiozea, and $G$. pseudomiocenica. Other foraminifers present are Globorotalia acostaensis, $G$. globorotaloidea, G. scitula, G. aff. humerosa, Globigerina bulloides, G. quinqueloba, G. microstoma, G. nepenthes, $G$. atlantica, $G$. decoraperta, Orbulina universa, Globigerinita glutinata, G. uvula, and Sphaeroidinellopsis seminulina.

The Globorotalia margaritae margaritae Zone (from Sample 4-1, 144-146 cm to Sample 4-2, 25-27 cm) with 
numerous $G$. margaritae margaritae, $G$. acostaensis, $G$. globorotaloidea, Globigerina bulloides, $G$. quinqueloba, in combination with rarer Globigerinita glutinata, G. uvula, Orbulina universa, Globorotalia scitula, G. humerosa, Globigerina microstoma, and $G$. concinna caps the Miocene.

\section{Pliocene}

Pliocene sediments are separated from those of the Miocene by a 66 meters interval wherein there was no recovery. The Pliocene sediments belong to the Globorotalia margaritae evoluta Zone (Sample 3-1, $80-82 \mathrm{~cm}$ ), and are characterized by the index species, $G$. margaritae margaritae, $G$. puncticulata, G. inflata, $G$. scitula, Globigerina bulloides, $G$. concinna, $G$. quinqueloba, Globigerinita glutinata, and Orbulina universa.

\section{Quaternary}

Another interval without recovery $(66.5 \mathrm{~m})$ separates Quaternary from Pliocene sediments. The apparent thickness of the Quaternary section is 71.5 meters; only two cores were recovered in the interval from 5 to 62 meters.

The lower part of the Quaternary oozes (from Sample 2-1, 144-146 cm to Sample 2-3, 86-87 cm) likely belongs to the Globorotalia crassaformis hessi Sub-zone. It is characterized by abundant Globortalia inflata, Globigerina bulloides, and $G$. quinqueloba accompanied by rarer Globorotalia crassaformis hessi, G. crassaformis crassaformis, G. puncticulata, G. scitula, G. crassula, Orbulina universa, Globigerinella siphonifera, Turborotalita humilis, and Neogloboquadrina pachyderma.

In the surface layers, 5 meters thick, two assemblages were observed. The lower (from Sample 1-2, 65-67 cm to Sample 1-3, 25-27 cm) abounds in Neogloboquadrina pachyderma associated with numerous Globigerina bulloides, G. quinqueloba, Globigerinita glutinata and rare Globorotalia inflata, G. scitula, G. acostaensis, Orbulina universa, and Turborotalita humilis, a relatively cold water microfauna.

The upper assemblage (Sample 1-1, 70-72 cm) reflects relatively warm water postglaciation (Holocene) conditions and consists of numerous Orbulina universa, Globigerina bulloides, G. quinqueloba, Globigerinita glutinata, Globorotalia inflata, G. scitula, G. acostaensis, G. crassaformis, G. hirsuta, and Turborotalita humilis; Globorotalia truncatulinoides was recognized and specimens of Neogloboquadrina pachyderma are rare.

\section{ECOLOGICAL AND CLIMATIC PECULIARITIES OF PLANKTONIC FORAMINIFERS}

Throughout Cenozoic time the Bay of Biscay and Rockall Plateau areas were associated to various climatic belts and experienced changing climates from subtropical to temperate to boreal. The Cenozoic sediments in these areas were deposited at various depths, the local ecologies of which coupled with climate, affected the composition of the planktonic foraminiferal biotas. The combination of the above factors with selective diagenetic dissolution determines the foraminiferal thanatocoenoses that are encountered in the sediments, but it is not always possible to differentiate which factor was the dominant influence.

The influence of selective dissolution on the systematic composition of foraminifers is well demonstrated at Site 400 (the present depth, $4399 \mathrm{~m}$ ). Here, Eocene and Oligocene deep-water sediments are characterized mostly by representatives of Acarinina and non-keeled Globorotalia, the so-called Turborotalia such as G. frontosa, G. opima, $G$. nana, the related Globigerina(?) boweri and other species of Globigerina such as Globigerinita unicava. There are no keeled Globorotalia, some Globigerina species, and representatives of Hantkenina, Globigerapsis, Globigerinatheca, Pseudohastigerina, and Truncorotaloides which are widely developed in synchronous more shallowwater sediments of Sites 401 and 402 .

In Neogene deep-water sediments of Site 400 Globorotalia (Turborotalia) with perforate peripheral margin are developed again, and include $G$. kugleri, $G$. nana, $G$. continuosa, $G$. siakensis, $G$. peripheroronda, $G$. acostaensis, $G$. crassaformis, $G$. inflata, $G$. puncticulata, and the phylogenetically related species of the $G$. fohsi group and $G$. margaritae. The common elements of this microfauna are Neogloboquadrina dutertrei and $N$. pachyderma, some species of Globigerina ( $G$. woodi, $G$. venezuelana, $G$. druryi, $G$. nepenthes, $G$. bulloides) and comparatively rare Globigerinita unicava, Sphaeroidinellopsis seminulina, S. subdehiscens, Globigerinita glutinata, and Globoquadrina dehiscens. Representatives of keeled Globorotalia are very rare (i.e., $G$. merotumida). Noteworthy is the almost complete absence of Globigerinoides species, and extremely rare keeled Globorotalia, Orbulina, and Praeorbulina.

The quantitative distribution and qualitative diversity of planktonic foraminifers in deep-water sites such as Site 400, as compared to the more shallow-water Sites 401 to 406 was controlled by a number of local bionomic factors.

At Site 400, sediments of the lower part of the lower Eocene and the lower part of the lower Miocene, with rather diverse planktonic foraminiferal assemblages, are separated by sediments of the upper part of the lower Eocene, middle Eocene, and Oligocene, wherein foraminifers are rare or sometimes absent. In their stead, the sediments contain siliceous organisms, the development of which is probably related to upwelling of cold waters, rich in nutrients that stimulated a flourish of siliceous plankton and benthos. Selective dissolution of planktonic foraminifers was probably only secondary in accounting for their paucity.

A similar picture is observed at Site 406 where Oligocene sediments (the Globorotalia opima Zone) are separated from Miocene sediments (the Praeorbulina glomerosa Zone), both with rich planktonic foraminiferal assemblages, by an interval of upper Oligocene-lower Miocene diatomites and diatom chalk characterized by abundant siliceous organisms and almost devoid of planktonic foraminifers. This flourish of siliceous organisms again is probably related to upwelling near the continental slope of the Rockall Plateau.

However, in deep-water sediments of Site 400 there are intervals (the upper part of the lower Miocene and the upper 
part of the upper Miocene), where both siliceous and calcareous plankton are extremely rare. In this instance the scarcity or absence of planktonic foraminifers is most likely related to the lowering of the carbonate compensation depth.

The close relation of planktonic foraminifers to the depth of accumulation of carbonate sediments is obvious. At Site 406, middle Eocene shallow-water calcareous-clayey sediments contain a poor, dwarfish fauna of them. They are also of poor systematic composition and of small size in glauconitic limestones of the middle Eocene at Site 403, and in analogous sediments of the lower Eocene at Site 405. Such similarities cannot be explained simply by cold-water conditions in a temperate area, because normal faunas, although rather poor in systematic composition, are developed stratigraphically higher in typically pelagic calcareous oozes of the upper Eocene, Oligocene, and Neogene.

The influence of climate on distribution of planktonic foraminifers has become obvious only since Cenozoic deposits have been penetrated by DSDP holes throughout the North Atlantic, from the equatorial area to the Norwegian and Greenland Seas.

In the tropical belt, from the Equator to Latitude 28 degrees North, Paleogene planktonic foraminifers have been studied in both the western and the eastern sectors, and Neogene and Quaternary foraminiferal studies from the belt of the Mid-Atlantic Ridge (See Initial Reports of the Deep Sea Drilling Project, Legs 1, 2, 3, 4, 10, 11, 14, 15, 41).

In Paleogene time the Bay of Biscay was situated in the subtropical belt, probably near its northern margin. From the limited material from that area, it appears that Paleocene and lower Eocene planktonic foraminifers differed slightly from tropical microfauna in the absence of Globorotalia occlusa, G. apanthesma, G. imitata, G. trichotrocha, $G$. pasionensis, G. elongata, G. quetra, G. marksi, Acarinina tribulosa, A. strabocella, and A. gravelli.

In middle Eocene time the difference is pronounced, as evidenced by the absence of Orbulinoides beckmanni, Globorotalia lehneri, Clavigerinella jarvisi, C. akersi, Hantkenina dumblei, and Globigerinita echinata; by the wide distribution of Acarinina species, especially $A$. rotundimarginata and $A$. bullbrooki; in the frequent occurrence of Hantkenina alabamensis, H. liebusi, and $H$. Lehneri; by the morphological peculiarity of Truncorotaloides rohri and $T$. topilensis being frequently devoid of accessory apertures; and by the presence of numerous small Globigerina such as $G$. incretacea, $G$. azerbaijanica, and $G$. pseudocorpulenta in the Truncorotaloides rohri Zone. The abundant Acarinina rotundimarginata in the Globorotalia lehneri Zone and Hantkenina alabamensis in the Orbulinoides beckmanni Zone has not been observed in the tropical areas. Whereas, middle Eocene assemblages of the Bay of Biscay are very similar to the synchronous microfauna of the Crimea and North Caucasus, deposited approximately at the same latitude, the latter microfauna differs slightly by still greater impoverishment in the absence of Hantkenina aragonensis, Globigerapsis kugleri, Globorotalia pseudomayeri, $G$. renzi, and $G$. spinulosa.
Differences between tropical and subtropical assemblages are clearly recognized in the upper Eocene sediments of the Bay of Biscay where the entire group of Globorotalia cerroazulensis ( $G$. cerroazulensis, $G$.cocoaensis, G. cunialensis), and Hantkenina alabamensis and H. suprasuturalis are absent, and Globigerapsis semiinvoluta and Cribrohantkenina inflata only sporadic. If sporadic specimens of the latter two species are disregarded, the upper Eocene assemblages from the Bay of Biscay and the Crimean-Caucasian area are identical, both consisting of mass accumulations of large Globigerina, Globigerapsis tropicalis, and $G$. index.

Comparison of subtropical planktonic foraminifers from the Oligocene and Neogene of the Bay of Biscay to those of the tropical belt is rather difficult. At Sites 401 and 402 calcareous organogenic oozes of the Oligocene and Neogene were eroded, and at Site 400 they are represented by deep-water sediments. The impoverishment of the assemblages may have been caused by selective dissolution and/or climatic influence. Noteworthy is the presence of the Globorotalia fohsi group in the Miocene. The Pliocene microfauna is much richer, but Sphaeroidinella, Pulleniatina, Candeina, Globigerinoides ruber, G. conglobatus, G. sacculifer, Globorotalia miocenica, $G$. exilis, and $G$. multicamerata are not present. The $G$. menardii group is barely developed.

As already noted, meagerness of the planktonic foraminiferal assemblages of the lower Eocene of Rockall Plateau (the temperate belt) is probably due to shallow-water conditions of sediment accumulation. Upwards in the section they are replaced by normal calcareous pelagic sediments and the number of forms abruptly increases (middle Eocene of Site 405). The assemblage consists of representatives of $\mathrm{Ar}$ cinita, Globigerina (including G. boweri), Pseudohastigerina micra, non-kelled Globorotalia ( $G$. bolivariana); keeled Globorotalia ( $G$. caucasica, G. aragonensis) are sporadic.

Excellent assemblages occur in the upper Eocene sediments of Rockall Plateau (Site 406). They consist of representatives of Globigerina, Globigerapsis ( $G$. tropicalis, G. index), and rare non-keeled Globorotalia (G. centralis). Species of Hantkenina, Cribrohantkenina, Globigerapsis semiinvoluta and the Globorotalia cerroazulensis group (G. cerroazulensis, G. cocoaensis, $G$. cunialensis) are entirely absent. These peculiarities distinguish upper Eocene assemblages of Rockall Plateau from those of the Bay of Biscay where sporadic Globigerapsis semiinvoluta and Cribrohantkenina inflata are still present, and make them identical, in specific composition, to the upper Eocene associations of the Crimea and North Caucasus. But, whereas in the latter region almost every species occurs in equal numbers, in the paleocoenoses of Rockall Plateau Globigerapsis tropicalis, Globigerina corpulenta, G. galavisi, G. praebulloides, and sometimes $G$. pseudovenezuelana sharply predominate and other species are rare.

The Oligocene assemblages (the Globorotalia opima Zone) of the Rockall Plateau Sites 403 and 406 abound in some species such as non-keeled Globorotalia (G. opima, $G$. nana), Globigerina praebulloides, Globorotaloides 
suteri, and Globigerinita unicava; other planktonic foraminifers are rare. As known, Septarian clays of North Europe, clays of the Carpathian Menilit Formation, calcareous and noncalcareous foliated shales of the Maicop Formation from Varna basin in Bulgaria to the Transcaspian area are characterized by the fauna of small Globigerina (G. officinalis, G. praebulloides, G. ouachitaensis, $G$. angustiumbilicata, etc.). The similar composition of Oligocene biotas of northern and eastern Europe has commonly been explained to result from general deterioration of climatic conditions in Oligocene time, and the relatively northern geographical position of the area. This explanation must be rejected because, much further north, in the Oligocene on Rockall Plateau, excellent assemblages of planktonic foraminifers are developed, including both the small and the large species of Globigerina and Globorotalia (Turborotalia). The presence of assemblages of minute Globigerinids in the Oligocene of northern and eastern Europe is related to the sandy-clayey, frequently slightly calcareous, sediments in which they accumulated.

The basal part of the lower Miocene on Rockall Plateau is composed of diatomites and diatomaceous chalk, and the nature of planktonic foraminifers for this unit is obscure. However, beginning in the upper part of the lower Miocene, the Neogene is characterized by abundant specimens, although the number of species is small. Five groups can be distinguished. Most prominent among them is: (1) the Globorotalia (Turborotalia) group with a rounded non-keeled peripheral margin $(G$. siakensis, $G$. peripheroronda, G. obesa, G. continuosa, G. acostaensis, $G$. humerosa, G. globorotaloidea, G. crassaformis). The author has never seen such enormous accumulations of G. siakensis in middle Miocene sediments, of $G$. acostaensis and G. globorotaloidea in upper Miocene sediments of the tropical and subtropical areas; (2) the Globigerina group (G. juvenilis, G.falconensis, $G$. foliata, G. bulloides, G. concinna, G. quinqueloba, and $G$. megastoma).

In the upper Miocene, Pliocene and Quaternary sediments these groups are supplemented by (3) a group of rather numerous Globorotalia miozea miozea, G. miozea conoidea, $G$. conomiozea, $G$. puncticulata, and $G$. inflata, observed in the subtropical area but rare or absent in tropical areas.

Stratigraphically important is (4) a group of eurythermal species, in small equal quantities of specimens developed in the tropical, subtropical and temperate-boreal belts. The group includes Globorotalia miozea cibaoensis, $G$. praemenardii, G. pseudomiocenica, G. margaritae margaritae, and $G$. margaritae evoluta.

Group (5) is composed of species occurring in subordinate numbers of specimens. It contains Globoquadrina altispira, G. dehiscens. Globigerina nepenthes, Globigerinoides trilobus, G. subquadratus, $G$. bollii, Globorotalia merotumida, G. aff. plesiotumida, Sphaeroidinellopsis seminulina, S. subdehiscens, Globigerinoides bisphaerica, Praeorbulina transitoria, $P$. glomerosa, Orbulina suturalis, $O$. universa, and others. Though they are seldom recognized, some of them are valuable stratigraphic markers as, for instance, in the lower/middle Miocene of Rockall Plateau where the trend Globigerinoides bisphaerica - Praeorbulina transitoria $P$. glomerosa - Orbulina suturalis - O. universa can be clearly traced.

Impoverishment of some forms in Neogene/Quaternary sediments of Rockall Plateau is manifested in complete absence of Globigerinatella, Cassigerinella, Candeina, Pulleniatina, Sphaeroidinella, the Globorotalia fohsi group, the Globorotalia menardii group as well as $G$. (Clavatorella) bermudezi, G. tumida, G. multicamerata, $G$. pertenuis, $G$. miocenica, and $G$. exilis. In addition there is weak development of representatives of Globigerinoides, many species of which $(G$. diminutus, $G$. obliquus, $G$. sacculifer, G. ruber, and $G$. conglobatus) are absent.

As a whole, Eocene, Oligocene, and Neogene assemblages of planktonic foraminifers of the Rockall Plateau area are of clearly pronounced temperate character and, in the latest stages of the Pliocene/Quaternary time, they sometimes acquired temperate-boreal features.

Unfortunately, it is difficult to estimate every stage of impoverishment of planktonic foraminiferal assemblages in Paleogene and Neogene sections of the area because general deterioration of climatic conditions in some intervals of the Cenozoic (lower and middle Eocene, part of the Oligocene, and lower Miocene) do not yield definitive material.

Noteworthy is the bipolarity of planktonic foraminiferal distribution. Globorotalia miozea miozea, G. miozea cibaoensis, G. miozea conoidea, G. conomiozea, $G$. puncticulata, $G$. inflata, and $G$. crassaformis, peculiar to the upper Miocene and Pliocene of Rockall Plateau, are representative of synchronous sediments in the temperate belt of the Southern Hemisphere (DSDP Legs 28 and 29).

Comparison of Cenozoic planktonic foraminiferal assemblages of the tropical, subtropical, and temperate areas shows: (1) general specific diversity of planktonic foraminifers decreases northward; (2) the ratio of species in paleocoenoses varies; (3) in the main a limited group of species is peculiar to the temperate belt; (4) there are irregularities in species distribution along the stratigraphic section, where they are characterized not by their own biozones, but by epiboles (teilzones).

\section{ZONAL STRATIGRAPHY OF CENOZOIC DEPOSITS OF THE BAY OF BISCAY AND THE ROCKALL PLATEAU}

Numerous bionomic factors affect the systematic composition of planktonic foraminiferal assemblages in such diverse ways that the Tertiary faunal zones, regardless of whether they occur in the same or in different latitudes, are never identically represented by the same genera and species. Indeed it is not uncommon to find that the fauna of a particular zone lacks the index species. Obviously the stratigraphic value of a zone is much greater when the complex spatial diversity of its fauna is understood and used rather than depending upon a few individual elements within it or the appearance or disappearance of the index species. As a result of this regional variation in the taxonomic composition of fauna, independent zonal scales have been erected in different areas. In 1954 the Paleogene Committee of the USSR adopted the Unified Zonal Scale of Paleocene and Eocene (subtropical-temperate belt) for the 
southern part of the USSR. The Oligocene and Miocene rocks of the southern USSR contain only marine intercalations separated by brackish and fresh water sediments. Zonal scales of Bolli (1957a, b, c) and Blow (1969) for the Paleogene and Neogene of the tropical and subtropical belts are well known and for the Cenozoic of Rockall Plateau (temperate-boreal area) an independent zonal scale has been created by Berggren (1972a).

For the Paleogene succession in the Bay of Biscay area, at least for middle and upper Eocene, the CrimeanCaucasian zonal scheme formally should be used. For the Neogene successions of the Bay of Biscay and Rockall Plateau, a zonation different to that of the standard tropical scale formally should be applied also. But the fact that some of the tropic elements are found in subtropic and temperate latitudes and the existence of sections with transitional microfaunas shows that the detailed Cenozoic zonal scale of the tropical zone is equally valid for the subtropical and temperate belts.

Zonal subdivisions, for the Cenozoic stratigraphy of the Bay of Biscay and Rockall Plateau, based on planktonic foraminifers, are summarized below. Figures 2 and 3 illustrate, respectively, the stratigraphic succession in the two areas. Because lower and middle Eocene sediments in the Rockall Plateau area are of shallow water-origin and poor in planktonic foraminifers, zonal units for sediments of these ages were recognized only in the Bay of Biscay.

Paleocene: the Globorotalia trinidadensis Zone, Site 401; the Acarinina uncinata Zone, Site 401; the Globorotalia pseudomenardii Zone, Site 401; the Globorotalia velascoensis Zone, Site 401 . Because of a hiatus within Paleocene only the Globorotalia pusilla s.1. Zone was not recognized.

Lower Eocene: the Globorotalia subbotinae Zone, Sites 400 and 401; the Globorotalia formosa Zone, Sites 400 and 401; the Globorotalia aragonensis Zone, Site 401; the Globorotalia palmerae Zone, Site 401.

Middle Eocene: the Hantkenina aragonensis Zone s.l., Site 401; the Globigerapsis kugleri Zone, Site 401; the Globorotalia lehneri Zone, Site 401; the Orbulinoides beckmanni Zone, Site 401; the Truncorotaloides rohri Zone, Sites 401 and 402.

In the upper Eocene of the Bay of Biscay the following were singled out: the Globigerapsis semiinvoluta Zone, Site 402; the Globorotalia cocoaensis Zone, Site 401; the Globorotalia centralis - Globigerina turritilina Zone, Site 401. The two first zones cited have weak distinctions because the guide species of these zones are presented by rare specimens; on Rockall Plateau they were determined as an undifferentiated unit at Site 406.

The Oligocene sections both in the Bay of Biscay and on Rockall Plateau are stratigraphically incomplete. The Globorotalia opima Zone is very well defined in both regions (Sites 400, 403, and 406); the Globigerina ciperoensis Zone (without the index species) was determined on Rockall Plateau, Site 406.

The lower Miocene of the two given regions is characterized by sediments unfavorable for planktonic foraminifers. The Globigerinoides primordius-Globorotalia kugleri Zone and the Globigerinita dissimilis Zone were recognized in the Bay of Biscay, Site 400 , and the
Praeorbulina glomerosa Zone, at Rockall Plateau, Site 406.

In the base of the middle Miocene at Rockall Plateau the Orbulina suturalis-Globorotalia peripheroronda Zone was recognized, Site 406 . In the Bay of Biscay this stratigraphic interval is represented by sediments with rare planktonic foraminifers; here, overlying sediments of the middle Miocene contain the Globorotalia peripheroacuta, Globorotalia fohsi lobata, Sphaeroidinellopsis subdehiscens-Globigerina druryi, and Globigerina nepenthes-Globorotalia siakensis zones (Site 400). On Rockall Plateau sediments of the same age cannot be subdivided into zones (Site 406).

The whole succession of zonal units of the upper Miocene can be traced in the Bay of Biscay and on Rockall Plateau; it contains the Globorotalia continuosa Zone, Site 400 and, conditionally, Site 406; the Globorotalia merotumida Zone, Sites 400, 403, 404, and 406; the Globorotalia plesiotumida Zone, Sites 400, 403, 404, and 406; the Globorotalia margaritae margaritae Zone, Sites 400, 403, 405, and 406.

On Rockall Plateau the Globorotalia merotumida Zone is recognized by the occurrence of Globorotalia miozea cibaoensis, unknown in more ancient sediments, and for the determination of the Globorotalia plesiotumida Zone it is the appearance of Globorotalia pseudomiocenica, also unknown in the underlying sediments. In the Globorotalia plesiotumida Zone the species $G$. pseudomiocenica is accompanied by numerous $G$. miozea conoidea, and $G$. conomiozea. These three species are common also in the Globorotalia margaritae margaritae Zone, but there they associate with the index species.

In the Pliocene of the Bay of Biscay and on Rockall Plateau the Globorotalia margaritae evoluta Zone is very distinct at Sites 400, 403, and 406. On Rockall Plateau the index species of this zone is accompanied by abundant Globorotalia puncticulata. Younger sediments of the Pliocene of the Bay of Biscay (Site 400) are subdivided into the Globorotalia miocenica and Globorotalia tosaensis zones, but this subdivision is conditional on account of the poverty of the microfauna (evidently, in connection with selective dissolution). On Rockall Plateau (Site 403) the same stratigraphic interval cannot be separated into indicated zones due to the impoverishment of microfauna of the temperate belt. However, here, two local subdivisions are pronounced, layers with Globorotalia crassaformis and layers with Globorotalia inflata.

Comparison of stratigraphic subdivisions of the upper Miocene/Pliocene sediments of Rockall Plateau (the temperate belt of the Northern Hemisphere) with the Tasman Sea (the subtropical-temperate belt of the Southern Hemisphere), based on data of Kennett (1973), and Kennett and Vella (1975), reveals similarities. The upper Miocene/Pliocene sediments of the Tasman Sea are subdivided into the Globorotalia continuosa, Globigerina nepenthes, Globorotalia conomiozea, Globorotalia margaritae, Globorotalia puncticulata, Globorotalia crassaformis, and Globorotalia inflata zones. Thus, a bipolarity of the zonal stratigraphic scales of the upper Miocene and Pliocene is recognized. However, if the zones of the upper Miocene and lower Pliocene are based on the evolutionary development of planktonic foraminifers, establishment of the Globorotalia crassaformis and 
Globorotalia inflata "zones" is based on epiboles of these two species. Coincidence, in general, of the stratigraphic scopes of the Globorotalia crassaformis layers and the Globorotalia inflata layers of the Northern Hemisphere and "zones" of the same name of the Southern Hemisphere suggests similar (universal) change of the climatic conditions, which determined, apparently, ecological flourishings (or subordinate position) of Globorotalia crassaformis and $G$. inflata in assemblages of planktonic foraminifers of the Northern and Southern temperate belts.

The Quaternary sediments correspond to the Globorotalia truncatulinoides Zone which was determined in all sites of the Bay of Biscay and Rockall Plateau. Paleontological data (ratio of planktonic foraminiferal species in their assemblages) in combination with the paleotemperature analysis $\left(\mathrm{O}^{16} / \mathrm{O}^{18}\right)$ should permit creation of the detailed climate-stratigraphy of Quaternary.

\section{SOME ASPECTS OF GEOLOGICAL HISTORY OF CENOZOIC}

Numerous discontinuities and hiatuses exist in the Cenozoic successions of the Bay of Biscay and Rockall Plateau. Within the Paleogene section of the Rockall Plateau, at Site 403, the lower Eocene, middle Eocene, and Oligocene are separated by disconformities and considerable intervals of Paleogene sediments are missing. At Site 406 disconformities separate the middle Eocene, upper Eocene, and Oligocene. These gaps in the record reflect unstable conditions of sedimentation which existed not only during accumulation of shallow-water clayey tuffaceous sediments of Paleocene-early Eocene age, but continued into the late Eocene and Oligocene when accumulation of deeper water pelagic organogenic oozes took place.

A regional discontinuity separates the upper Miocene from older deposits. It is present at all sites on Rockall Plateau. Its regional character is emphasized by the fact that different zones of the upper Miocene (Globorotalia continuosa, Globorotalia merotumida, and Globorotalia margaritae margaritae) rest on sediments of different ages, i.e., middle Miocene (Site 406), Oligocene (Site 403), middle Eocene (Site 405), lower Eocene (Site 404). Even in two neighboring sites the age of sediments below this disconformity are widely diverse: Oligocene at Site 403 and lower Eocene at Site 404.

In contrast, sediments of the upper Miocene/Quaternary are remarkable for their stratigraphic completeness (Sites 403, 404 and 406); only in Site 405 do Quaternary oozes disconformably overlie the Globorotalia margaritae margaritae Zone (the uppermost Miocene), but this disconformity appears to be distinctly localized because, in the adjacent Site 406, the section is continuous.

Examination of the lithology and flora/fauna at sites on Rockall Plateau reveals significant interpretable information. The oldest Paleogene in Sites 403 and 404 (sandstones, tuffs, clays, lignitic clays), conditionally attributed to the upper Paleocene, lack faunal remains. Accumulation of these deposits evidently took place under subaerial conditions. Higher up, in basal Eocene layers are rare, sometimes rounded shells of benthic foraminifers and debris of mollusks; these sandstones, clays, and tuffs probably should be considered to be littoral deposits. Overlying lower Eocene sediments are characterized by diverse benthic foraminifers, ostracodes, bryozoa, sponges, and sea urchins; rare planktonic foraminifers occur here. These sediments obviously accumulated in a sublittoral area.

Sediments of the upper part of the lower Eocene (within the limits of the Globorotalia aragonensis and Globorotalia palmerae zones) are distinguished by another type of microfauna, the bulk of which consists of abundant radiolarians. Occasionally planktonic foraminifers are numerous but their specific composition is impoverished because of the development of the radiolarian facies (Sites 404 and 405). Such a microfauna should be considered to be pelagic; their accumulation proceeded evidently at the margin of the shelf and in the upper part of the continental slope.

Analogous pelagic radiolarian-foraminiferal oozes are peculiar to the basal part of the middle Eocene (Sites 405 and 406), whereas exceptional pelagic foraminiferal and radiolarian-foraminiferal oozes were developed in the upper Eocene (Site 406) and Oligocene (Sites 403 and 406).

From this it is evident that subsidence of Rockall Plateau proceeded rather quickly, the amplitude of subsidence being equivalent to present-day depths of 2300 to 2900 meters.

The Cenozoic of the Bay of Biscay displays an irregular picture of the stratigraphic position of discontinuities, although sites are located close to each other. At Site 400 upper Paleocene rocks rest disconformably on the Maestrichtian; at Site 401 the contact of the Danian and Maestrichtian stages is essentially conformable, but higher up the section a gap within the Paleocene (between the Acarinina uncinata and Globorotalia pseudomenardii zones) is present; at Site 402 sediments of the upper part of the middle Eocene overlie those of the Lower Cretaceous (Albian).

At Site 400 Oligocene sediments rest disconformably on those of the middle Eocene but higher up, a continuous section of Oligocene, Neogene, and Quaternary follows; at Sites 401 and 402 sediments of this age are all but missing and the upper Eocene is directly overlain by Quaternary. For explanation of such a variegated picture of hiatuses and disconformities, it is difficult to find reasons.

The entire Cenozoic section of the Bay of Biscay is characterized by pelagic facies; the main subsidence of this region appears to have been a Mesozoic event.

\section{ACKNOWLEDGMENTS}

We express our sincere gratitude to $\mathrm{Co}$-Chief Scientists of Leg 48, Dr. L. Montadert (Institut Français du Pétrole, France) and Dr. D. Roberts (Institute of Oceanographic Sciences, England), for the possibility of obtaining and publication of materials of this leg of Glomar Challenger. Our sincere thanks also to Dr. P.P. Timofeev (Geological Institute of the USSR Academy of Sciences, USSR) for his helpful suggestions.

\section{REFERENCES}

Berggren, W. A., 1972a. Cenozoic biostratigraphy and paleobiogeography of the North Atlantic. In Laughton, A S., Berggren, W.A., et al., Initial Reports of the Deep Sea Drilling Project, v. 12: Washington (U.S. Government Printing Office), p. 965-1002. 
1972b. Late Pliocene-Pleistocene glaciation. In Laughton, A. S., Berggren, W. A., et al., Initial Reports of the Deep Sea Drilling Project, v. 12: Washington (U.S. Government Printing Office), p. 953-964.

, 1974. Late Paleocene-Early Eocene benthonic foraminiferal biostratigraphy and paleoecology of Rockall Bank, Micropaleontology, v. 20, no. 4.

Blow, W. H., 1969. Late Eocene to recent planktonic foraminiferal biostratigraphy, First International Conf. Planktonic Microfossils Proc.

Bolli, H. M., 1957a. The genera Globigerina and Globorotalia in the Paleocene-lower Eocene Lizard Springs formation of Trinidad, B.W.I., U.S. Nat. Mus. Bull. 215.

1957b. Planktonic Foraminifera from the Eocene Navet and San Fernando formation of Trinidad, B.W.I., U.S. Nat. Mus. Bull. 215.

1957c. Planktonic foraminifers from the Oligocene-Miocene Cipero and Lengua formations of Trinidad, B.W.I., U.S. Nat. Mus. Bull. 215.
Kennett, J. P., 1973. Middle and Late Cenozoic planktonic foraminiferal biostratigraphy of the Southwest Pacific, DSDP Leg 21. In Burns, R. E., Andrews, J. E., et al. Initial Reports of the Deep Sea Drilling Project, v. 21: Washington (U.S. Government Printing Office), p. 575-640.

Kennett, J. P. and Vella, P. 1974. Late Cenozoic planktonic foraminifera and paleoceanography at DSDP Site 284 in the cool subtropical South Pacific. In Kennett, J. P., Houtz, R. E., et al., Initial Reports of the Deep Sea Drilling Project, v. 29: Washington (U.S. Government Printing Office), p. 769-800.

Laughton, A. S., Berggren, W. A., et al., 1972. Initial Reports of the Deep Sea Drilling Project, v. 12: Washington (U.S. Government Printing Office).

Poore, R. Z. and Berggren, W. A., 1975. Late Cenozoic planktonic foraminiferal biostratigraphy and paleoclimatology of Hatton-Rockall Basin: DSDP Site 116, J. Foram. Res., v. 5 , no. 4 . 